\title{
Excavations on the Site of Balmerino House, Constitution Street, Leith
}

\author{
Ross H M White \& Chris O'Connell
}

\author{
With contributions by \\ Sue Anderson, Dennis Gallagher, George Haggarty, \\ Derek Hall, Andrew Heald, Adam Jackson, Dawn McLaren \\ \& Catherine Smith
}


Published by the Society of Antiquaries of Scotland, www.socantscot.org.uk with Historic Scotland, www.historic-scotland.gov.uk and the Council for British Archaeology, www.britarch.ac.uk

Editor Helen Bleck

Produced by Archétype Informatique SARL, www.archetype-it.com

ISBN: 9780903903585

ISSN: $1773-3803$

Requests for permission to reproduce material from a $S A I R$ report should be sent to the Director of the Society of Antiquaries of Scotland, as well as to the author, illustrator, photographer or other copyright holder.

Copyright in any of the Scottish Archaeological Internet Reports series rests with the SAIR Consortium and the individual authors.

The maps are reproduced from Ordnance Survey material with the permission of Ordnance Survey on behalf of The Controller of Her Majesty's Stationery Office. (C) Crown copyright 2001. Any unauthorised reproduction infringes Crown copyright and may lead to prosecution or civil proceedings. Historic Scotland Licence No. GD 03032G, 2002.

The consent does not extend to copying for general distribution, advertising or promotional purposes, the creation of new collective works or resale. 


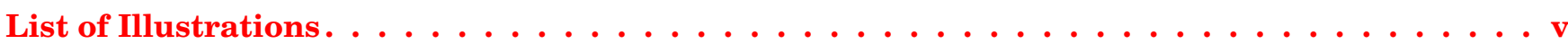

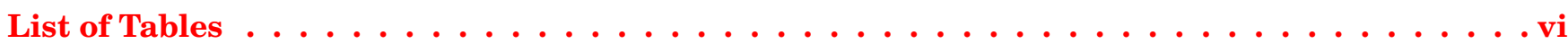

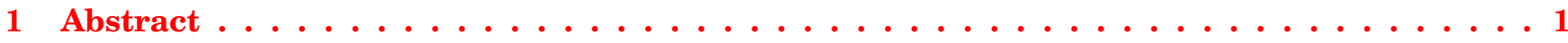

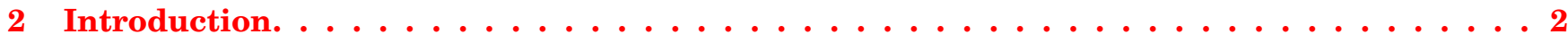

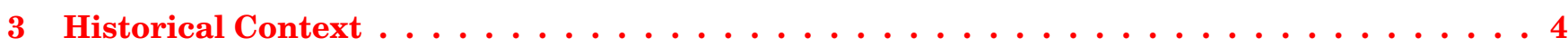

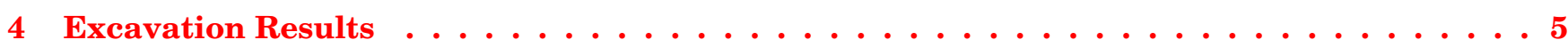

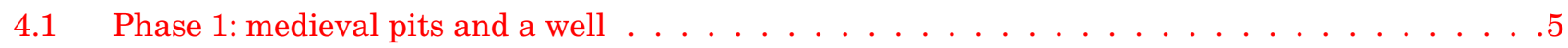

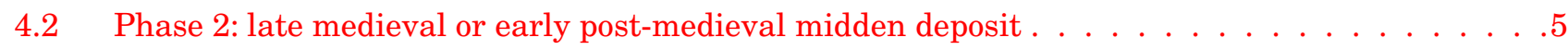

4.3 Phase $3:$ early post-medieval quarry pits $\ldots \ldots \ldots \ldots \ldots \ldots \ldots$

4.4 Phase 4 : skeletal remains and overlying midden layer $\ldots \ldots \ldots \ldots \ldots$

4.5 Phase 5 : Balmerino House construction . . . . . . . . . . . . . . . . . . . . . . . . . . .9

4.6 Phase 6: demolition and modern levelling . . . . . . . . . . . . . . . . . . . 12

4.7 Uncertain phases . . . . . . . . . . . . . . . . . . . . . . . . . 12

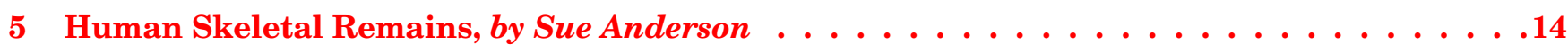

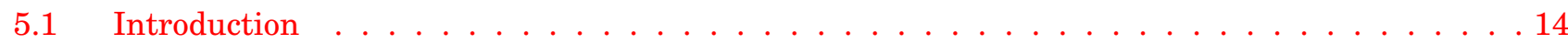

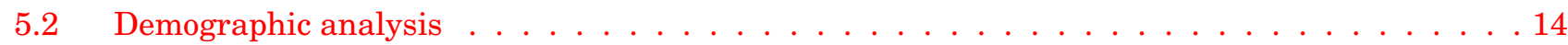

5.3 Metrical and morphological analysis . . . . . . . . . . . . . . . . . . . . 14

5.4 Dental analysis . . . . . . . . . . . . . . . . . . . . . . . . . 14

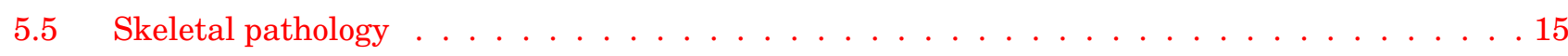

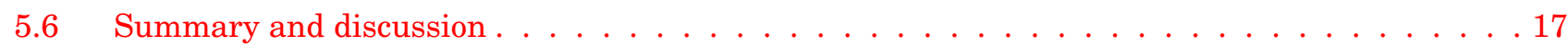

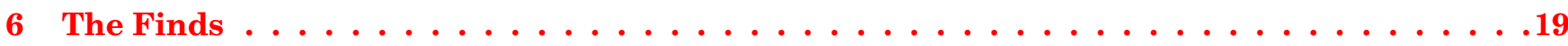

6.1 Pottery, by Derek Hall and George Haggarty . . . . . . . . . . . . . . . . . . . . 19

6.2 Clay pipes, by Dennis Gallagher . . . . . . . . . . . . . . . . . . . . . . . 21

6.3 Ceramic building material and fired clay, by Sue Anderson . . . . . . . . . . . . . 21

6.4 Stone, by Adam Jackson ～. . . . . . . . . . . . . . . . . . . . . . . . . 22

6.5 Glass, by Sue Anderson . . . . . . . . . . . . . . . . . . . . . . 222

6.6 Metalwork, by Sue Anderson . . . . . . . . . . . . . . . . . . . . . . . 23

6.7 Vitrified material, by Dawn McLaren and Andrew Heald . . . . . . . . . . . . . . . . . 23

6.8 Worked bone, by Catherine Smith . . . . . . . . . . . . . . . . . . . . 24

6.9 Animal bone, by Catherine Smith . . . . . . . . . . . . . . . . . . . . 24

6.10 Overview of the finds and dating evidence, by Sue Anderson . . . . . . . . . . . . . 27 
7 Site Narrative . . . . . . . . . . . . . . . . . . . . . . . . 29

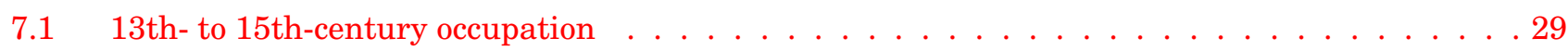

7.215 th/16th-century abandonment or cultivation $\ldots \ldots \ldots \ldots \ldots$

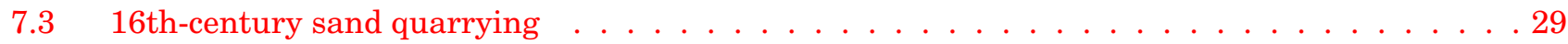

7.4 Late 16 th-/early 17 th-century burial ground . . . . . . . . . . . . . . . . . . . 29

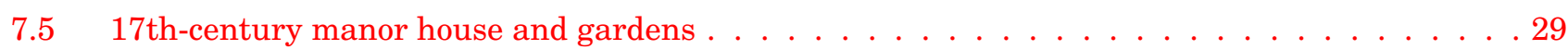

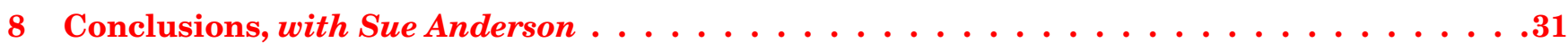

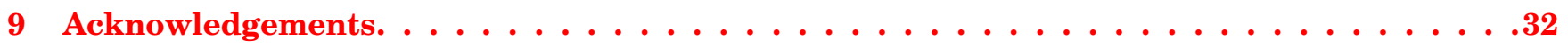

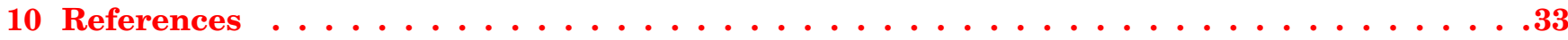




\section{LIST OF ILLUSTRATIONS}

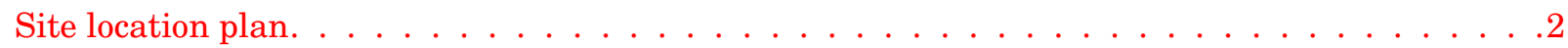

Phase 1 plan . . . . . . . . . . . . . . . . . . . . . . . . 6

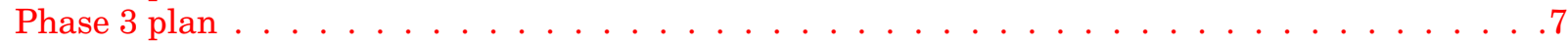

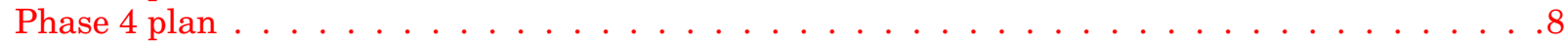

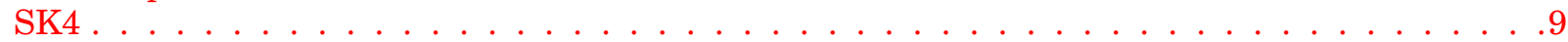

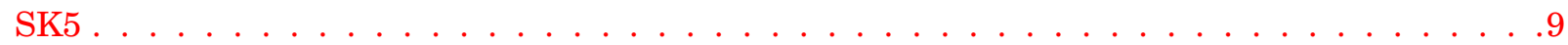

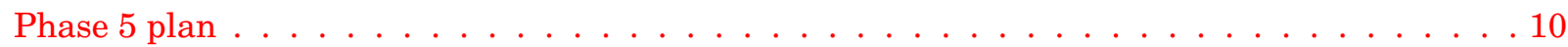

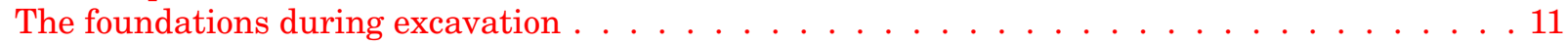

Balmerino House in the 19 th century. . . . . . . . . . . . . . . . . . . . . . 12

Probable clay pipe wear on the mandibular canine and first premolar of SK5 . . . . . . . . . 15

Two well-healed and remodelled fractures in a right mid rib of SK5 . . . . . . . . . . . . . 16

Depressed fracture on the right side of the frontal bone of SK5 . . . . . . . . . . . . . 16

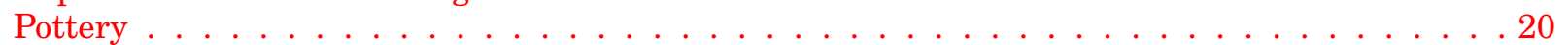

Glass stem . . . . . . . . . . . . . . . . . . . . . . . 222

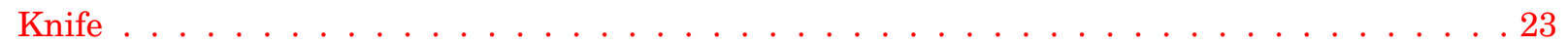




\section{LIST OF TABLES}

1

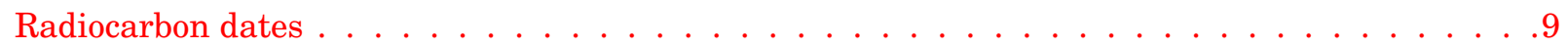

2

Age and sex of human skeletons $\ldots \ldots \ldots \ldots \ldots \ldots \ldots \ldots \ldots$

Animal- and bird-bone species quantification by phase $\ldots \ldots \ldots \ldots \ldots \ldots$ 


\section{ABSTRACT}

The remains of the front of Balmerino House, built in 1631, were uncovered during an archaeological excavation at St Mary's Star of the Sea Roman Catholic Church, Constitution Street, Leith. The work also revealed several phases of medieval to post-medieval activity, and a small burial ground which predated the house. The earliest feature uncovered by the excavation was a well containing 13 th- to 14 th-century pottery. Large quantities of late to post-medieval pottery were recovered, as well as iron objects, glass and bone. The human remains comprised six adult males, although some were incomplete due to later disturbance. Of importance to the history of clay tobacco pipe manufacture in Scotland is a small assemblage of clay-pipe wasters and kiln waste dated $c$ 1630-40. The work was sponsored by Gregor Properties Ltd. 


\section{INTRODUCTION}

Excavations carried out at St Mary's Star of the Sea Roman Catholic Church, Constitution Street, Leith (illus 1, NGR NT 2711 7616) identified the remains of Balmerino House, as well as areas of late to postmedieval activity, including a burial site. The work was carried out in advance of the construction of a new church hall.
An evaluation (White 2004) was undertaken in February 2004 and uncovered the remains related to the eastern elevation of Balmerino House. Based on these results an excavation was conducted to uncover the extent of the remains within the footprint of a new building to be erected next to the existing presbytery. An area measuring approxi-
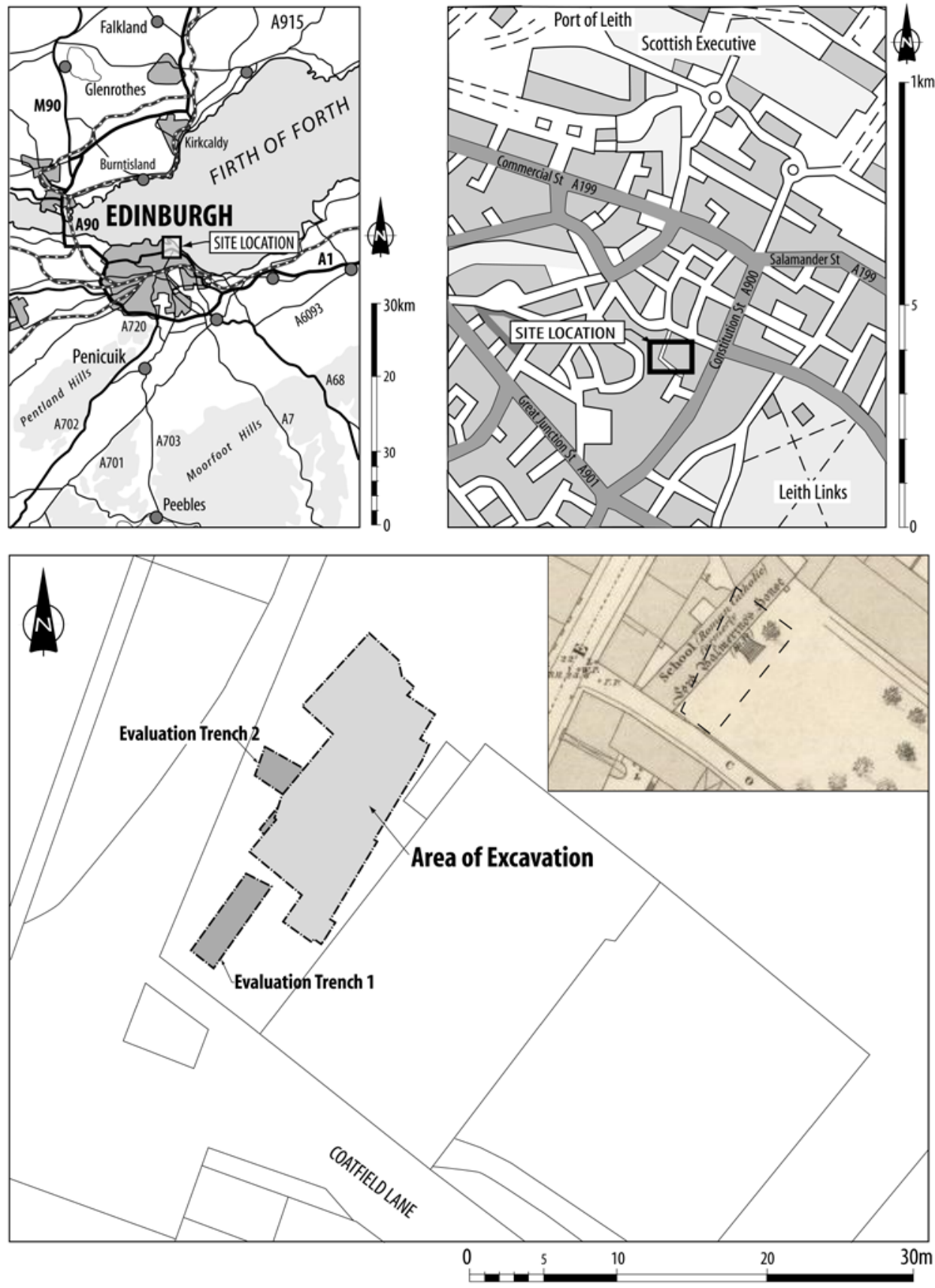

Illus 1 Site location plan, with inset showing location of the plot and Balmerino House on the 1st Edition OS map 
mately $20 \mathrm{~m} \times 11 \mathrm{~m}$ was excavated by machine to the first archaeological layer and all subsequent excavation took place by hand. The development area was most recently a tarmac car park with a garage at the back of the present presbytery. A brick wall enclosed the western and southern boundaries of the site.
Six phases of occupation, construction and demolition were identified. In summary from the earliest to the latest, these were: pits and a well; midden deposits; further pits; the remains of four inhumations and a further midden; the construction of Balmerino House; and the modern levelling of the site. 


\section{HISTORICAL CONTEXT}

Leith lies to the north of Edinburgh, at the mouth of the Water of Leith. The earliest recording of any settlement appears in the foundation charter of Holyrood Abbey, issued by David I in 1128 (Mowat 1994, 1). Excavations by the City of Edinburgh Council Archaeology Service (CECAS) in the 1990s at Burgess Street and Ronaldson's Wharf have provided evidence for this early 12th-century settlement, with the latter providing evidence for the pre-Burgh settlement (Lawson forthcoming a \& b). The port grew throughout the 12th and 13th centuries, and Leith became the main trading port in Scotland after the Wars of Independence in 1333, although the import and export trade coming through the port was not controlled by Leithers as Leith was not a Royal Burgh, but was instead controlled by the burgesses and merchants of Edinburgh, who severely curtailed the trading activities of Leith's inhabitants.

In 1544 and again in 1547, Leith was burnt by English troops on the orders of Henry VIII during a period known as 'the rough wooing', in which the English king attempted to enforce the Treaty of Greenwich, which betrothed the infant Queen Mary to his son, the future Edward VI. Henry's aggressive tactics forced Scotland into alliance with France and, at the instigation of the Catholic Mary of Guise, who ruled Scotland as regent from 1544 , substantial fortifications were constructed in Leith, which were occupied by a garrison of French troops. When Elizabeth I came to the throne in 1558, the Protestant Lords of the Congregation rebelled against Catholic rule and, with the support of English troops, besieged Leith in 1560. Ultimately the confrontation resulted in the Treaty of Edinburgh (under which the French agreed to destroy the fortifications in Leith and go home), the eventual fall of the Catholic Church in Scotland and the end of the Franco-Scottish Alliance. The site would have lain just within the defences on the eastern side of the fortress (Harris 1991).

In the 17th century the plague struck Leith, most notably in 1645 , when almost half the town's population died. Leith fell to Cromwell's troops in 1650, and was used as the Parliamentarians' Scottish headquarters for much of that decade.

A full historical analysis of Balmerino House was beyond the scope of this project, although it would be merited if further work were carried out on the site in the future. In summary, it was built in 1631 by John Stewart, Earl of Carrick, and sold to Lord Balmerino in 1643 (Grant 1882). Several generations of Balmerinos were resident in the house until the fifth Lord Balmerino, who died in January 1746, seven months before his brother, the sixth Lord Balmerino, was executed for his part in the 1745 Rebellion. After this the house changed hands several times and the land was eventually sold to the Church in 1848. St Mary's Star of the Sea was built in 1853 and Balmerino House was finally demolished in the 1970s. 


\section{EXCAVATION RESULTS}

The natural subsoil was loosely compacted, naturally free-draining yellow sand, which was present across the site and varied in depth from $1.8 \mathrm{~m}$ below the present ground surface in the north to $1.2 \mathrm{~m}$ below the present ground surface in the south. The site was stratigraphically phased into six periods, in part based on the presence of two major deposits assigned to Phases 2 and 4. The first (226) sealed the medieval deposits of Phase 1 and contained medieval pottery, and possibly signalled a period of abandonment (Phase 2). The second, Phase 4 deposit (212), sealed the early post-medieval features, including the burials, and contained later medieval pottery.

\subsection{Phase 1: medieval pits and a well (illus 2)}

A stone-lined well (262) was identified in the north of the excavation trench. The sub-oval pit was lined with unbonded cobblestones. It measured $1.1 \mathrm{~m}$ wide but the full length was not uncovered. Groundwater was encountered at $2.7 \mathrm{~m}$ below the present ground level, which prevented further excavation. The well was filled with several layers of sandy deposits, which contained oyster shells, sherds of 13th- to 15th-century pottery and fragments of bone.

Two small pits, 276 and 280 , were identified to the south of the well. They were both filled with browngrey silty sand which contained fragments of bone, pottery and glass. Pit 276 had been re-cut by another small sub-circular pit (278), which was centrally located within the earlier pit and filled with an organic silty clay. Small quantities of medieval and late medieval pottery and bone were retrieved from both pits.

An east-west-running gully (274) was identified bisecting the site. It was linear in plan, and filled with dark greyish-brown silty sand. This gully appeared to run perpendicular to the Kirkgate and possibly represented the remains of a property boundary. Pottery obtained from the fill of the gully was dated to the 15 th century.

In the southern half of the trench, a large pit (285) was cut into the subsoil. This pit was sub-circular in plan, and had silted up with sandy deposits.

A foundation cut (270) for a wall (350) had been excavated into the natural subsoil. The foundation cut could be seen in plan and section on the north side of the wall only. The curving section of wall 350 comprised large sub-rounded stones, and was probably of dry-stone construction as no evidence of mortar was recovered. Five courses of stonework were exposed before excavation ceased due to obstruction by overlying structural features left in situ. Abutting the proposed inner face of the wall and filling the foundation cut (270) was a deposit of grey-brown sand (271), from which the remains of a domestic fowl and a fragment of late medieval glazed floor tile were recovered. The full extent of wall 350 could not be determined, as it appeared to project under the overlying later walls (207 and 294), and could not be seen to continue south of them, possibly because it was cut by Phase 5 pits (214 and 237). Wall 350 was sealed by deposit 226 (Phase 2). Interpretation of the structure formed by wall 350 is uncertain, but it appears similar in form to well 262 at the north end of the site.

\subsection{Phase 2: late medieval or early post-medieval midden deposit}

A deposit of dark brown silty sand (226) sealed the Phase 1 features and overlay the subsoil at a depth of $1.2 \mathrm{~m}$ beneath the modern ground surface. This deposit was $c 0.23 \mathrm{~m}$ thick and was present across the whole trench. It contained fragments of bone and pottery sherds, and may be interpreted as a midden deposit. Most of the pottery collected from this layer was medieval, although the assemblage included German stoneware of 17th-century date, which was probably intrusive. An alternative explanation for this material is that it is a wind-blown deposit associated with late medieval abandonment of the site, a phenomenon reported elsewhere in Leith, such as at Water Street (Stronach 2002).

\subsection{Phase 3: early post-medieval quarry pits (illus 3)}

The third phase of activity on the site is represented by the remains of two large pits in the southern side of the excavation trench. The full extent and shape of these pits were never resolved, as they had been cut away by later features within the trench.

Pit 338 cut through the deposit (226) of Phase 2. It contained numerous layers of sands and gravels that had been tipped in from the south-west. It is not known whether the sand and gravel layers were dumped deposits or whether they had been deposited through erosion. Two of the earlier fills contained abraded Scottish White Gritty Ware pottery, and a later fill contained brick fragments compatible with a 16th-century date. The full extent of the pit was not identified, as it partially underlay the eastern 


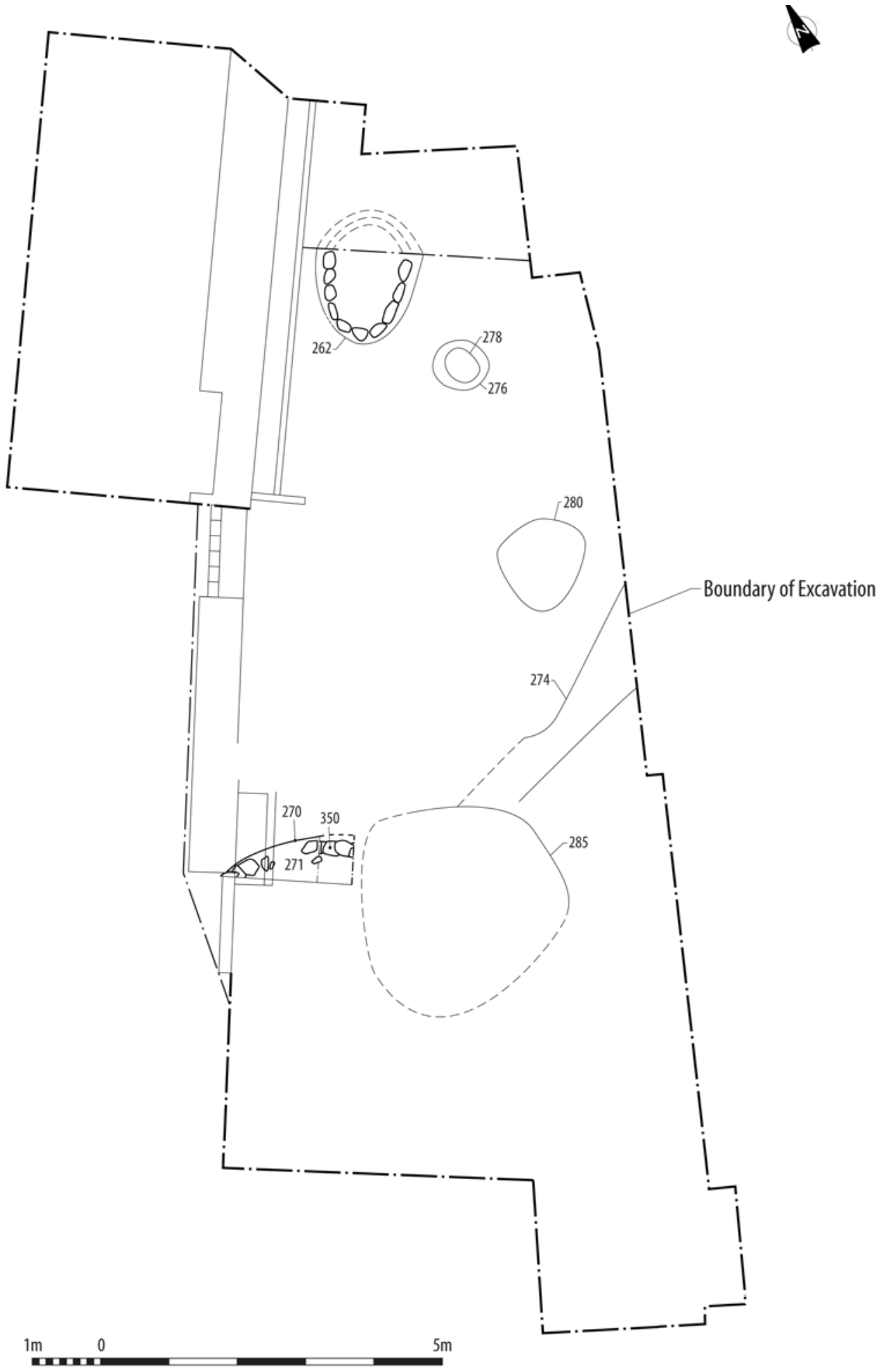

Illus 2 Phase 1 plan

trench edge and was cut through by successive phases of activity.

A second pit (282) was subsequently cut through the south side of pit 338. Once more the full extent of this pit was not fully identified as it disappeared under the baulk at the south end of the trench. It contained one sherd of post-medieval oxidised ware, fragments of smithing slag and animal bone.

\subsection{Phase 4: skeletal remains and overlying midden layer (illus 4)}

The remains of at least six individuals were recovered in the south-east of the trench, cut into the two large pits of Phase 3. Four discrete burials (SK1, SK2, SK4 and SK5) were identified, none of which was complete, due to modern disturbance. They were 


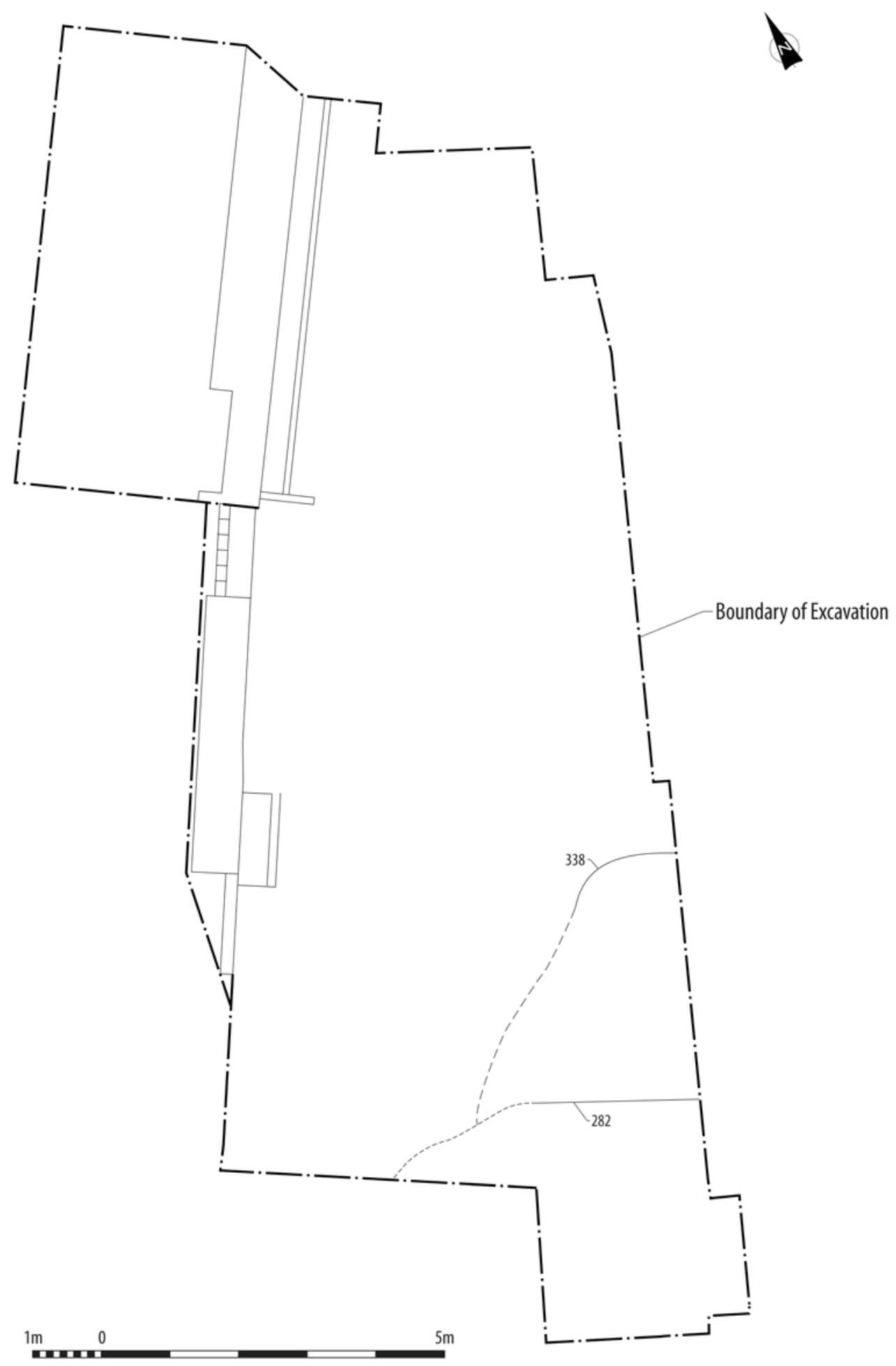

Illus 3 Phase 3 plan

all aligned NNE-SSW. No grave cuts were identified, except around SK5. The skeletons were found between $1.1 \mathrm{~m}$ and $0.95 \mathrm{~m}$ below the modern surface of the site. Other skeletal material was recovered from the overlying mixed deposit.

SK1 had been truncated at the knees by a modern service trench. The body was in a supine position and fully extended. Its left arm ran down its side and its right arm was bent to lie over the torso. Two sherds of Scottish White Gritty Ware were redeposited finds from the possible fill of this grave.

SK2 was positioned about $1 \mathrm{~m}$ to the south-west of SK1. The body was in a supine position but the legs were bent slightly at the knees and the feet were laid one on top of the other. Both arms were bent at the elbows and the hands placed over the pelvis. 


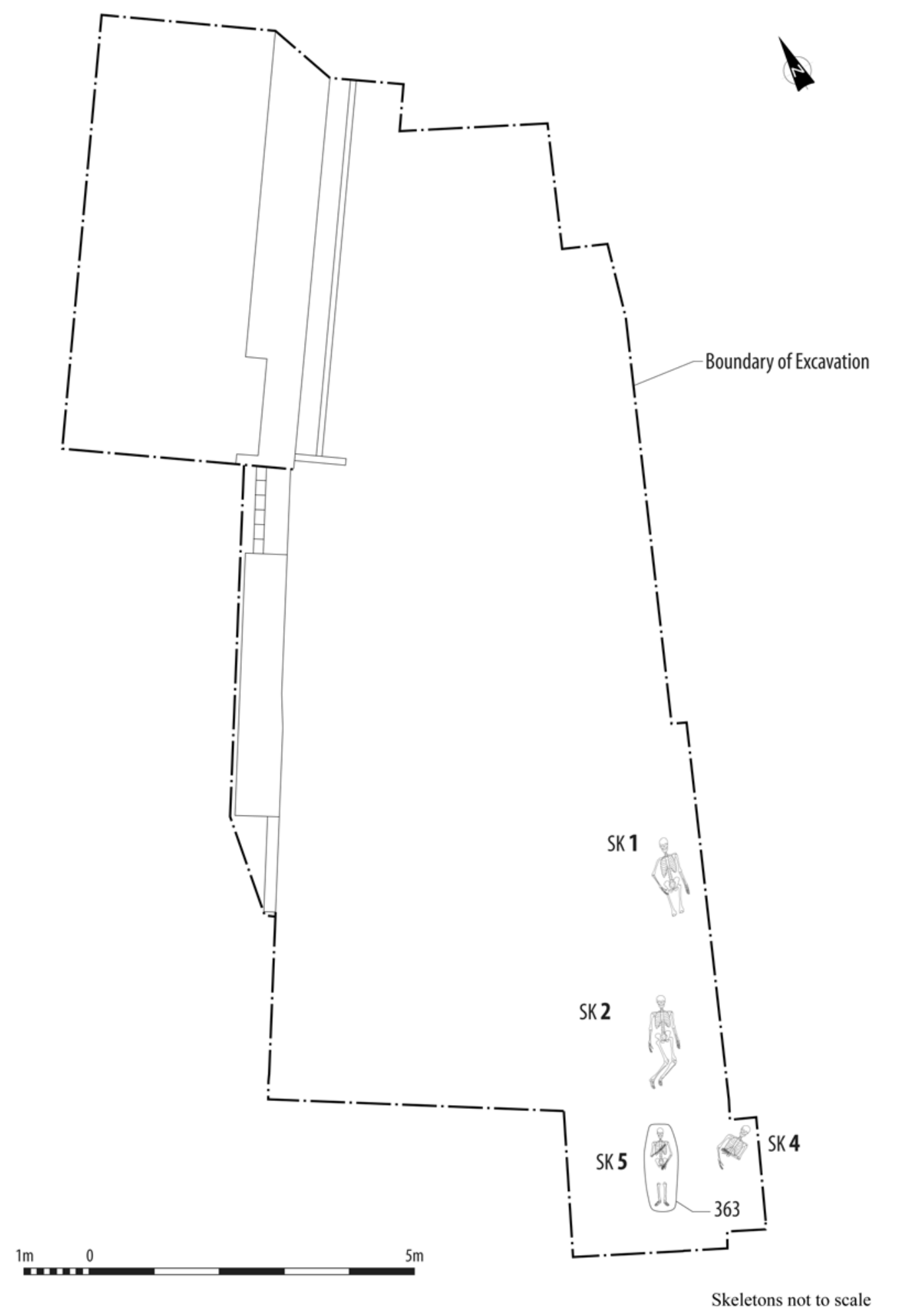

Illus 4 Phase 4 plan

SK4 was positioned about $1.3 \mathrm{~m}$ to the south-east of SK2. It was supine (illus 5) but had been severely disturbed by a later service trench running east to west. The cut had removed some of the lower vertebrae, the hips and all of the legs except the feet. The arms were folded across the lower chest area and the feet were very close together. Five nails were recovered in the fill surrounding this skeleton.
SK5 was positioned just to the south of SK2, lying in a supine position (illus 6 ). It had been truncated by a service trench running east to west. The cut had removed the skeleton from the base of the spine to just below the knees. A cut for this grave was identified, which measured $2 \mathrm{~m}$ in length and had a maximum width around the shoulders of $0.61 \mathrm{~m}$. The eastern side of the grave and the head area were cut 


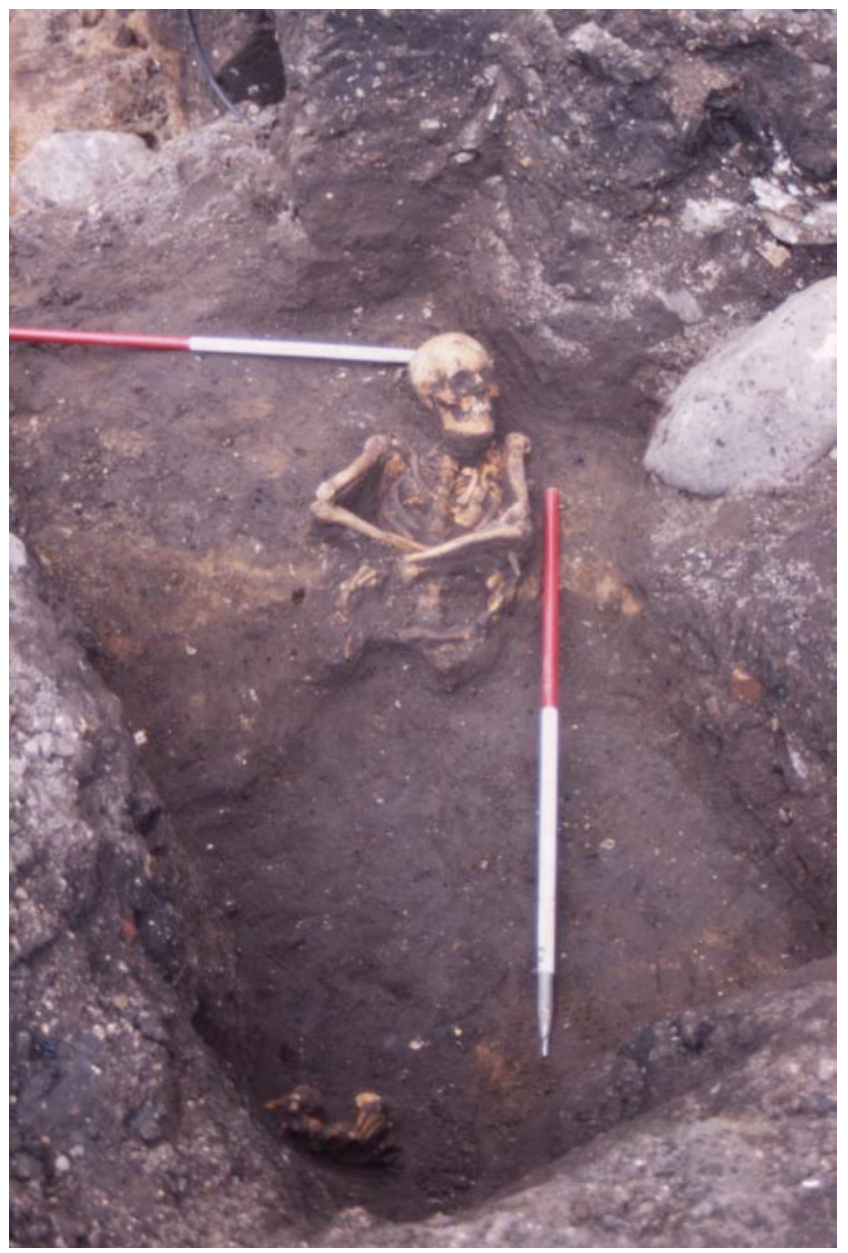

Illus 5 SK4

into natural yellow sand. Pottery associated with this skeleton was dated to the 15 th/16th centuries, and one large nail or stud was also recovered.

A mid-brown silty sand layer (212) sealed the skeletons. The layer, which contained sherds of late medieval pottery and fragments of bone and oyster shells, had been heavily disturbed and mixed by later activity. It covered the entire extent of the trench outwith the footprint of Balmerino House.

\subsubsection{Radiocarbon dates}

Samples of bone were selected from skeletons SK1 and SK5 for radiocarbon dating. The objective was to identify where the skeletons fitted into the sequence of events on the site. Radiocarbon assays were carried out at SUERC Radiocarbon Dating Labo-

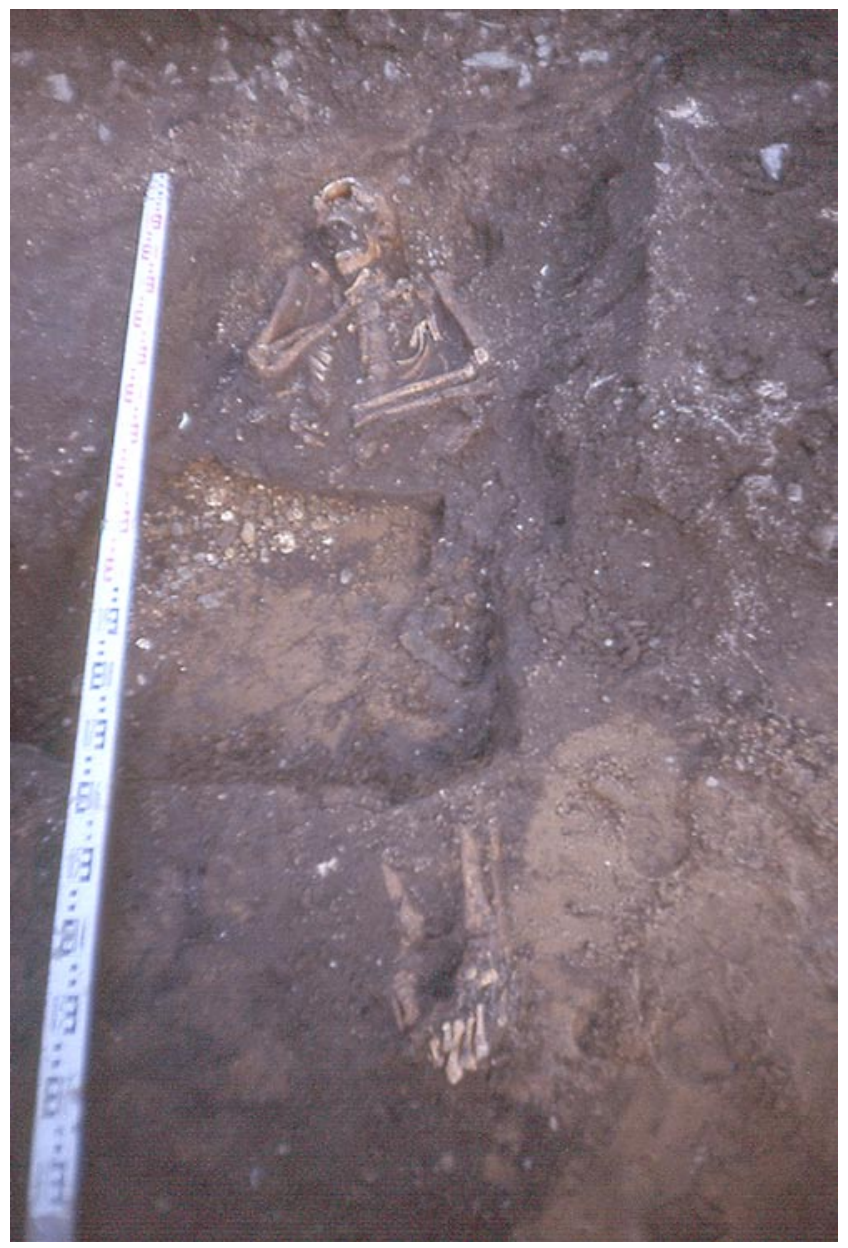

Illus 6 SK5

ratory, Scotland, and dates were calibrated using OxCal software v3.10. The results are presented in table 1.

The dates of the two skeletons are statistically indistinguishable, both being compatible with a date between the early 16 th and mid 17 th centuries. The burials pre-dated the construction of Balmerino House in 1631 on stratigraphic grounds.

\subsection{Phase 5: Balmerino House construction (illus 7-8)}

The partial remains of foundations for Balmerino House were identified during the evaluation stage of the work. The evaluation trench was expanded to encompass the footprint of the proposed new building, revealing further parts of the structure.

Table 1 Radiocarbon dates

\begin{tabular}{llcccc}
\hline Lab no. & Sample & C14 date bp & $\begin{array}{c}\text { Calibrated } \\
\text { date at 1-sigma }\end{array}$ & $\begin{array}{c}\text { Calibrated } \\
\text { date at 2-sigma }\end{array}$ & $\delta 13 C \%$-s \\
\hline SUERC-5369 (GU-12753) & SK1, L. radius & $315 \pm 40$ & AD 1510-1650 & AD 1470-1650 & -19.2 \\
SUERC-5370 (GU-12754) & SK5, L. ulna & $380 \pm 40$ & AD 1440-1620 & AD 1440-1640 & -18.9 \\
\hline
\end{tabular}




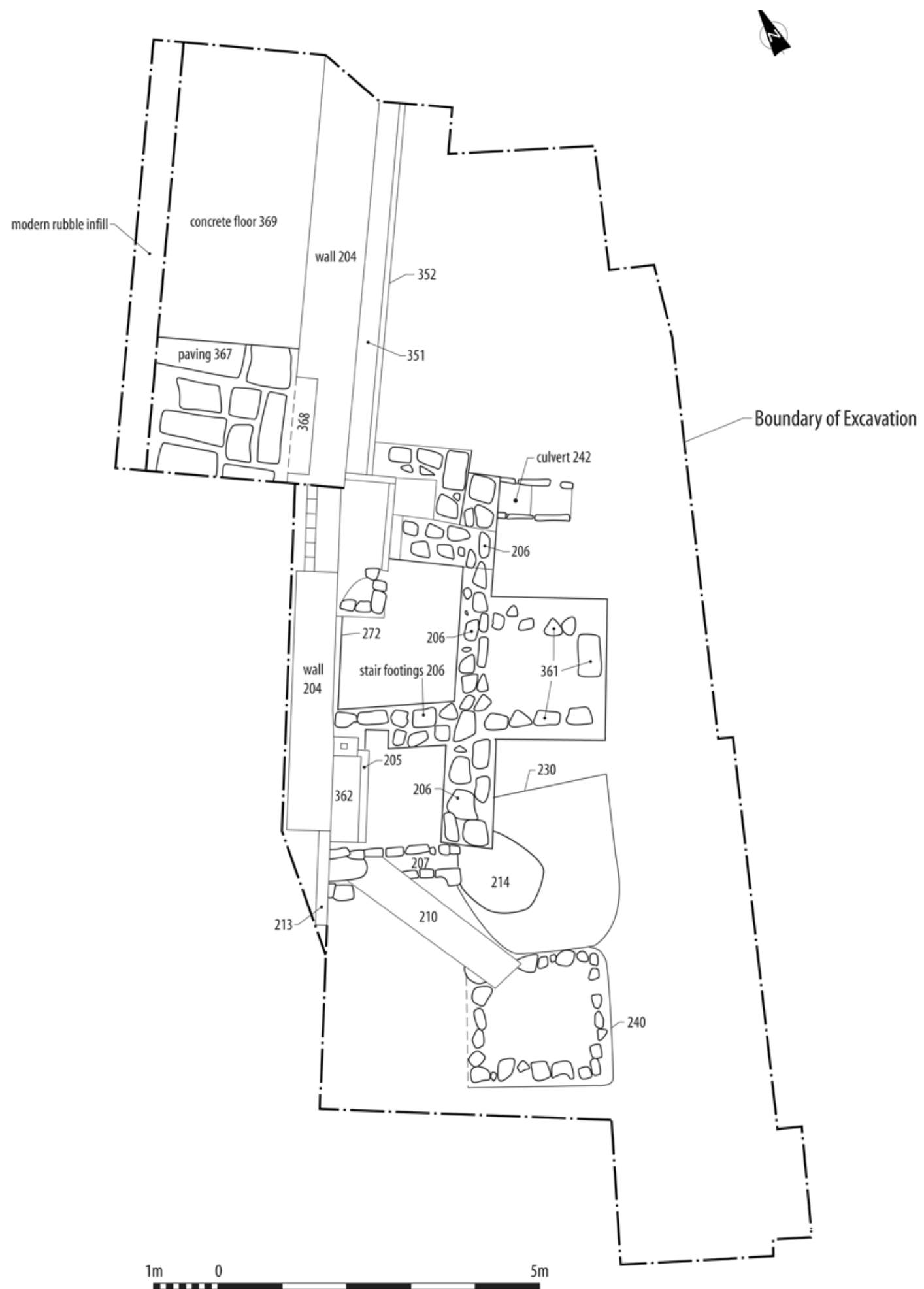

Illus 7 Phase 5 plan

An interpretation of the construction sequence of the house was produced by reference to the physical evidence from excavation, literary, cartographic and pictorial sources.

The excavated remains formed part of the eastfacing aspect of Balmerino House, which faced onto the grounds and gardens of the house (illus 9; Grant $1882,221)$. They included a retaining wall for the raised garden and grounds, the foundations of the sweeping staircase, and elements of the house's drainage system.

Wall 204 was the retaining wall for the raised grounds at the front of the house. The wall was of a substantial size, constructed of unworked rubble cemented together with a yellowish sandy mortar and cut through the Phase 4 midden deposits. A 


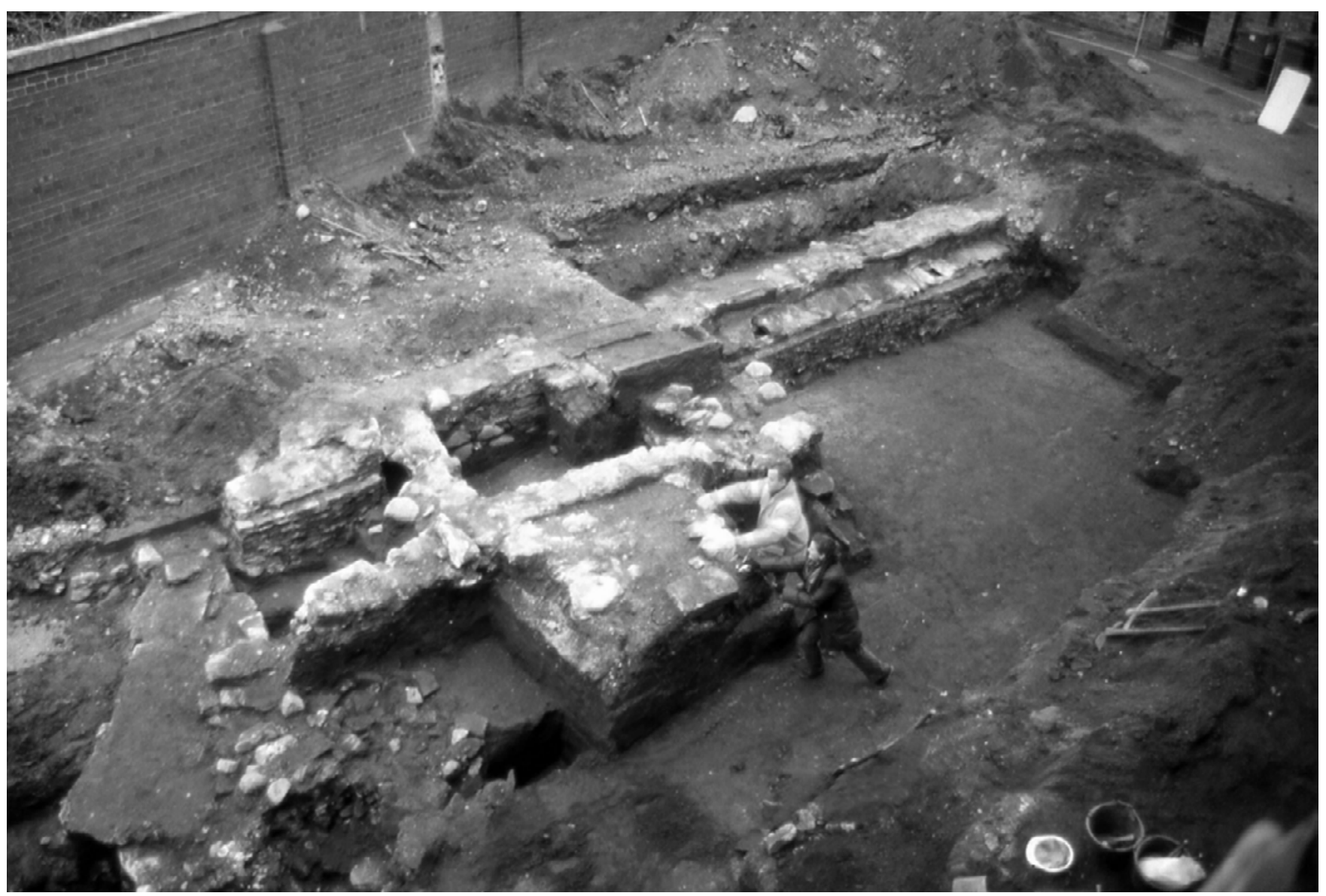

Illus 8 The foundations during excavation

brick-lined recess (368) was cut into the west-facing side of wall 204, the function of which could not be ascertained, but it may have been a decorative feature. The upper courses of the eastern elevation of wall 204 were dressed with red bricks (205 and 352 ) and finished with coping stones (351 and 362) along its length. The coping stones covered a gutter that ran the length of this section of wall and presumably found an outlet into culvert 242. A hole for a downpipe into this gutter was located at the north-eastern end of the wall. This downpipe would presumably have run down the north-eastern corner of the house, via the north-east to south-west return of wall 204, which was not present within the excavation trench.

Between wall 204 and the presumed position of the east elevation of the house, which was not present within the excavation trench, was a $2 \mathrm{~m}$ wide and $1.8 \mathrm{~m}$ deep sunken level which was paved at its south-western end with large, flat flagstones (367), laid directly onto natural sand, and to the north-east with a concrete skim (369). The existence of this sunken area was also extrapolated from Grant's depiction of the house (illus 9), in which the three lower windows to the north of the stairs were partially obscured by the raised grounds in front. Whether this sunken 'ambulatory' at the front of the house continued south of the stairs cannot be ascertained, as this area was beyond the limits of the excavation.

The foundations of the front steps (206) projected south-east from wall 204 and their construction cut through the Phase 4 midden deposits. The foundation walls themselves were built upon a midbrown sandy silt and consisted of mortar-bonded stone walls, $0.75 \mathrm{~m}$ wide by $0.85 \mathrm{~m}$ deep, forming a rectangle. The surrounding ground was then built up level with the top of the foundation walls. Within the rectangle formed by the foundation walls a dump of mid-brown sandy silt was used to make up the level. Around the outside of the foundation a series of deposits were used to build up the ground level.

Less substantial stone foundations ran out to either side and to the front (361) of the main front step foundations. Generally these smaller foundations were only $0.25 \mathrm{~m}$ deep. These less massive elements of the foundations were built upon successive levelling deposits, which seem to have been laid for the purpose. One of these was a layer of crushed mortar, presumably laid down to provide a firm base.

A large sump (230) was identified just to the south of, and partially underneath, the front step foundations. It was filled with large boulders to assist drainage, and a discrete dump of kiln material and fragments of early 17th-century clay tobacco pipes 


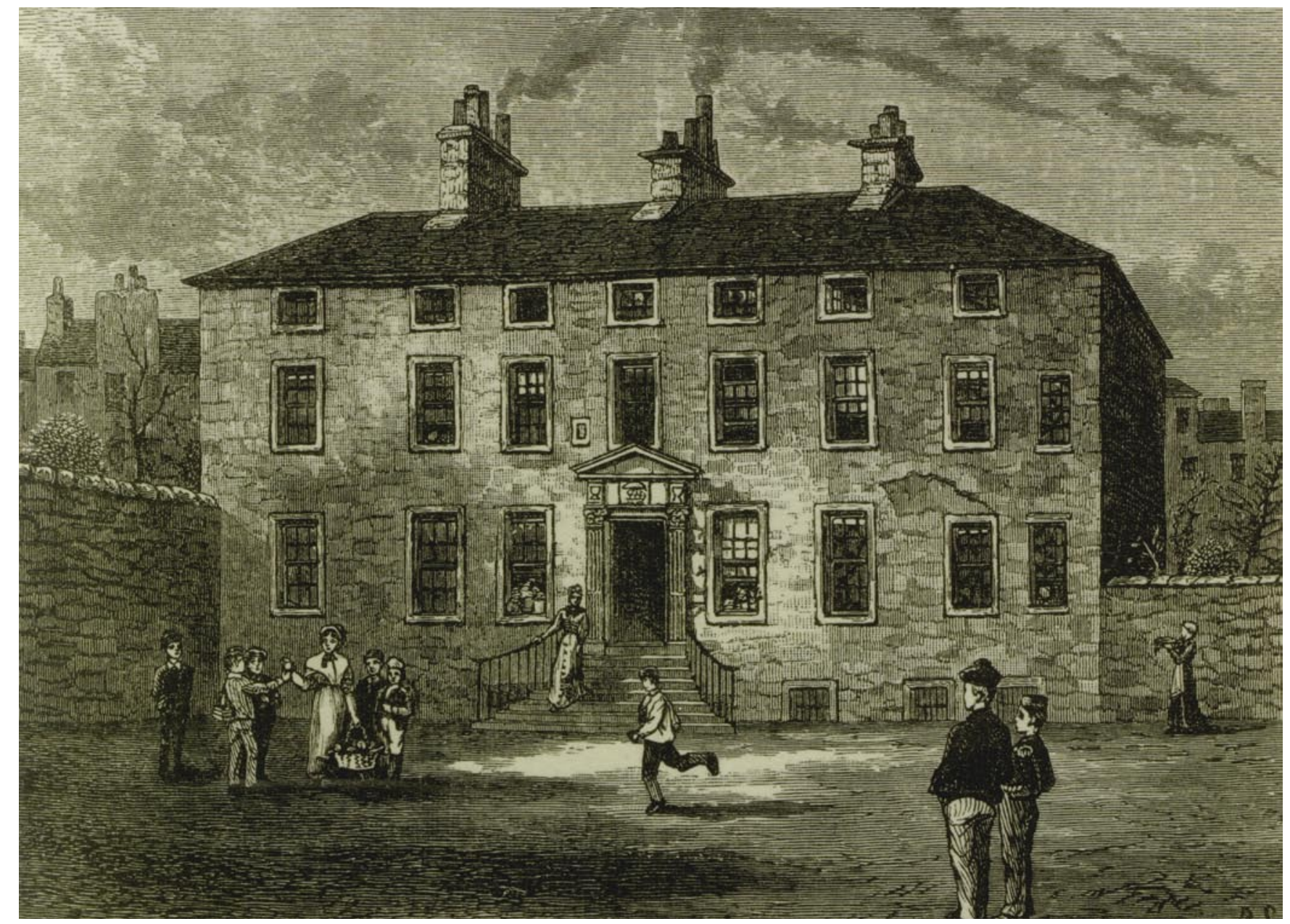

Illus 9 Balmerino House in the 19th century (after Grant 1882)

(214) was found towards the top of the sump. A stone culvert (207) passed under a lintel (213) and fed into the sump from the drain that ran along the front of the house. A later, square, stone-lined sump (240), located immediately to the south-west, replaced the earlier one, and a covered drain (210) diverted the flow from the earlier drain (207) into this new sump. The evidence of an earlier sump (230) partly sealed by foundation wall 206 suggests that either the stone staircase was later than the sump and associated culvert, or the staircase did not project as far out at the time the sump was constructed.

A covered box drain (242) was identified under the north side of the step foundation. It was not possible to follow the full extent of the drain to the west, due to the overlying deposits and walls, but its position in relation to the house and its morphological similarity to the stone culvert (207) suggests it was connected with rainwater drainage. It drained into the natural sand with no associated sump.

\subsection{Phase 6: demolition and modern levelling}

The demolition of Balmerino House and the in-filling of its interior to level the ground for a car park took place in the 1970s. The paved sunken area at the front of the house had been in-filled with rubble and modern rubbish during its demolition. The latest deposits, overlying the whole trench, consisted of a layer of Type 1 hardcore, surfaced with tarmac.

\subsection{Uncertain phases}

A clay-bonded wall (349), founded directly on to the natural sand, was identified parallel with, but underneath, the southern side of the foundations of the steps (206) and underneath the north-east to south-west-aligned retaining wall (204). The retaining wall was stepped up over wall 349, which ran south-east from the retaining wall, presumably because it was easier to do this than to demolish wall 349. It could not be accurately fitted into the stratigraphic sequence, as its relationship with features other than Balmerino House could not be ascertained, although it was certainly earlier than the Phase 5 construction, and the clay-bonded construction used in this wall is typically medieval. This wall, with sump 230, provides indications of an earlier structure on the site.

The skeleton of a dog (SK3) was discovered in a 
grave in front of Balmerino House. The grave cut through the Phase 2 midden layer and therefore post-dates Phase 2; however, the Phase 4 midden layer above the grave was heavily mixed by later activity so the skeleton cannot be securely placed within one of the later phases. Nevertheless, considering the development of the site and the location of the dog skeleton, just in front of Balmerino House, it seems likely that it represents the burial of a pet of one of the residents of the house. 


\section{HUMAN SKELETAL REMAINS by Sue Anderson}

\subsection{Introduction}

Four inhumations were excavated (SK1, 2, 4, 5), all of them disturbed and incomplete. A few disarticulated remains were also collected from two contexts and as unstratified finds. A full report and catalogue are available in the site archive.

The four identified burials were all discrete individuals, but fragments of at least one other adult were collected with SK4 and SK5 and as disarticulated remains. There was at least one sub-adult, represented by only two bones. The minimum number of individuals is therefore six.

Most of the bone was in good condition, although post-depositional disturbance had affected all the graves, and many bones were fragmented. The long bones of SK2 were less well preserved than the torso and several fragments showed signs of surface erosion.

\subsection{Demographic analysis}

Table 2 shows the ages and sexes of the six individuals identified in the analysis. All six individuals were male or probably male. This may indicate that some kind of selection was taking place, although the group is too small to allow any definite conclusions.

\subsection{Metrical and morphological analysis}

Measurements were taken for each of the main adult skeletons, and stature could be calculated for all four. They ranged from $168.3 \mathrm{~cm}\left(5^{\prime} 6^{\prime \prime}\right)$ to $178.3 \mathrm{~cm}$ (5'10"), which is relatively tall for a post-medieval population. Studies in Norwich (Anderson 1998) and elsewhere (eg Mays 1990) have shown that 17th/18thcentury individuals were often shorter than earlier and later groups. The largely medieval cemetery of The Hirsel, Coldstream, produced an average male stature of $168.0 \mathrm{~cm}$ (Anderson forthcoming).

Table 2 Age and sex of human skeletons

\begin{tabular}{lll}
\hline SK & Sex & Age \\
\hline 1 & Male & $c 25-30$ \\
2 & Male & Middle-aged \\
4 & Male & Middle-aged/old \\
5 & Male & Middle-aged/old \\
- & Male & $c 25-30$ \\
- & ?Male & $c 16$ \\
\hline
\end{tabular}

Three cranial indices were calculated. Two were broad-headed (brachycranial) and one was narrowheaded (dolichocranial).

Non-metric traits were scored for the bones present and these are listed in the archive. The results of this analysis produced no evidence which could confirm the presence of family relationships within the group. With the exception of bilateral fronto-temporal articulation in SK4, nothing unusual was seen. Three of the four individuals with skulls had lambdoid wormian bones, and this trait was also present in a fragment of skull from the Phase 4 midden layer (212), but it is relatively common in most archaeological populations and may be environmentally rather than genetically determined. One individual, SK1, had retained the metopic suture, the dividing line between the two halves of the frontal bone which is normally obliterated in childhood. Allen's fossa of the femur was present in SK1 and SK2, but these two individuals had no other traits in common.

\subsection{Dental analysis}

Dentitions of three individuals were available for study. This number is too small for any analysis of prevalences, so the three will simply be described.

SK1 had a complete maxilla and mandible. Three of his third molars were probably congenitally absent, and the fourth was partially erupted at the time of death. All other teeth were present in the jaw. There were medium-heavy calculus deposits, especially labially on all anterior teeth, and lingually on the mandibular teeth. Alveolar resorption was slight but there was no evidence for periodontal disease. Shallow U-shaped wear was seen on the upper and lower second incisors and canines; this type of wear is often associated with clay tobacco pipe use.

The maxilla of SK4 was damaged on the right side at the molar end, and it was not possible to tell whether the third molar had been present. It was congenitally absent in the mandible on both sides, but lost post mortem in the left maxilla. Two other teeth, the upper right second incisor and second premolar, had been lost post mortem. Ante-mortem loss had affected five teeth, premolars and molars, all in the maxilla. Five abscesses were present, also in the maxilla, affecting both canines, the left first premolar, and the right second premolar and first molar. Six teeth were carious: the origins of the lesions were interstitial cervical on the upper right second molar, buccal cervical on the lower right second molar and lower left first and second molars, and also lingual cervical on the lower left 
first molar. The crowns of the upper canines and the left first premolar had all been lost, and on the evidence of the lower left first molar it seems likely that carious lesions on both sides of the tooth at the cementum-enamel junction had eventually taken enough of the root for the crown to break off. There was slight-medium calculus on the remaining teeth, and considerable alveolar resorption, particularly of the mandible, with signs of infection in the maxilla.

The complete dentition was present in SK5. The upper right third molar was congenitally absent, but was present on the right, and had been lost in the lower right position; the lower left position was uncertain. The lower right second molar was also lost. Both this and the third molar had enlarged alveoli with pitted floors and abscesses and it is unclear whether they were lost ante or post mortem. The lower left second molar was lost ante mortem. All other teeth were present. Calculus was generally slight, but heavy on the labial surfaces of the anterior mandibular teeth. There was moderate alveolar resorption. Possible clay pipe wear was observed on the lower right canine and first premolar (illus 10).

A high level of dental pathology is often found in early post-medieval groups and has been attributed to an increase in sugar consumption, but generally this would occur at a later date than has been determined for these individuals. In Edinburgh and in Leith itself, the sugar-refining industry was founded in the mid 18th century (Grant 1882, ch 26, 235), and sugar was probably not widely available to the masses until the following century.

\subsection{Skeletal pathology}

\subsubsection{Congenital and developmental anomalies}

The sacrum of SK1 was damaged, but a few fragments showed that there was either sacralisation of the last lumbar vertebra or incomplete lumbarisation of the first sacral segment. As there appeared to be only four sacral segments, and there were five lumbar vertebrae, the latter seems most likely. A similar defect was noted in SK2, although in this case there was lumbarisation of the twelfth thoracic vertebra. Both individuals also had cleft defects of the neural arch at the sacral fourth and fifth segments only.

\subsubsection{Deficiency disease}

Cribra orbitalia was present in one of three individuals for whom the condition was assessable. The single example (SK1) was porotic and very minor. This condition is associated with iron deficiency anaemia.

Pitting, striation and thickening of the upper part of the cranial vault was noted in three of the

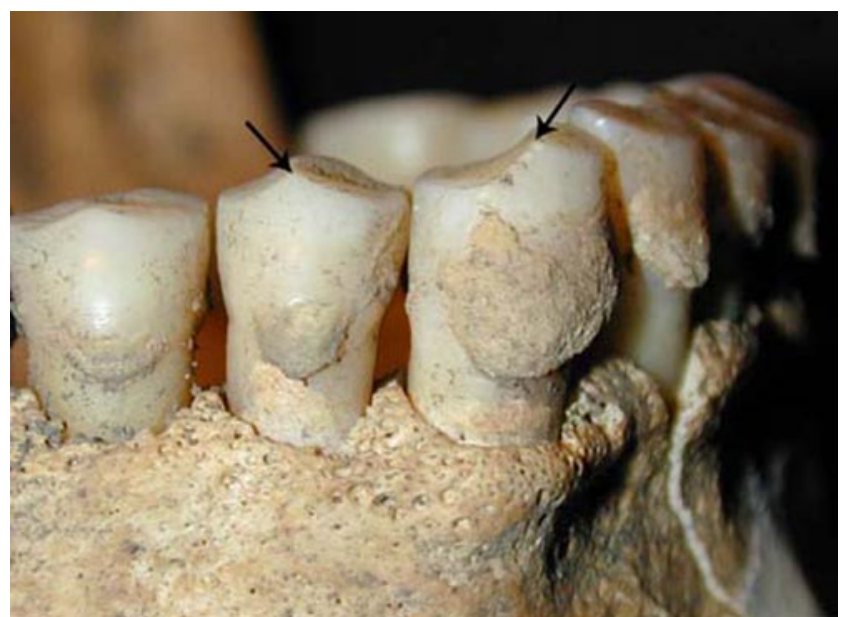

Illus 10 Probable clay pipe wear on the mandibular canine and first premolar of SK5, also showing heavy calculus deposits on the anterior teeth

four articulated individuals and in a disarticulated fragment of parietal bone. This may be healed porotic hyperostosis, another condition which has been associated with iron deficiency anaemia, but which may also occur in other deficiency diseases such as scurvy and rickets. However, an inflammatory response such as this could also be the result of a scalp infection.

\subsubsection{Degenerative disease}

Three individuals, SK2, 4 and 5, showed degenerative changes to the skeleton. These were mild in SK2, consisting of slight osteophytes on the lower thoracic vertebrae.

SK5 also had slight osteophytes on the lower thoracic and lumbar spine, as well as larger examples in the neck, particularly between the fifth and sixth cervical vertebrae. New bone growth and lipping also occurred in the left elbow (ulna trochlea borders) and the big toe joints (first metatarsal heads, right proximal hallucial phalanx). Calcified thyroid cartilage was present, and calcification of the costal cartilage at the anterior rib ends had also begun. Small periarticular cysts and new bone growth were noted in the left wrist (lunate) and right thumb (proximal pollicial phalanx), but there was no other evidence to suggest one of the less common forms of arthropathy.

Osteophytes were present in the lower thoracic and lumbar vertebrae of SK5, but in this case some of the vertebral facets were also affected, and at least one facet for a rib head (ninth thoracic vertebra). Large rounded exostoses on the right side of the first to third lumbar vertebrae were typical of the type seen in ankylosing hyperostosis, but had not fused by the time of death. Osteophytes were also present on the lateral side of the right ulna at the joint with the radius head. 


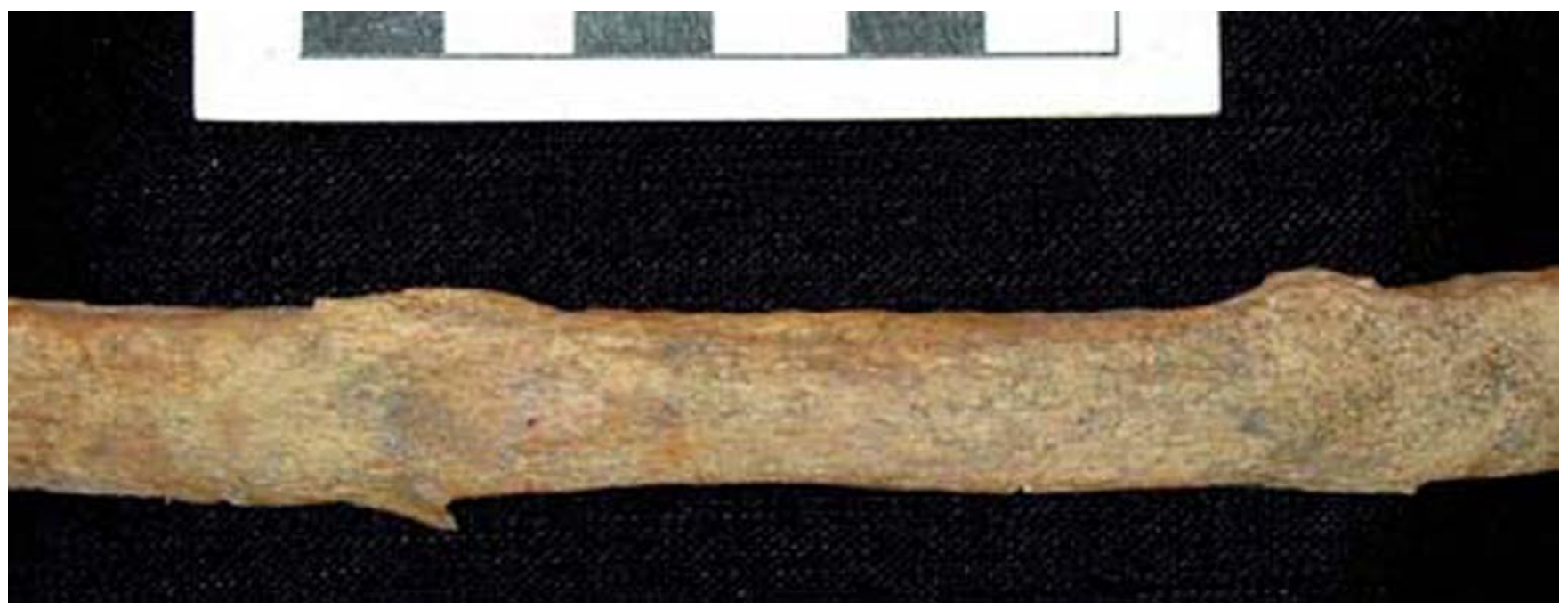

Illus 11 Two well-healed and remodelled fractures in a right mid rib of SK5

\subsubsection{Trauma and evidence of physical stress}

Schmorl's nodes of the vertebral bodies were present in the mid to lower thoracic area of SK1, the mid thoracic to mid lumbar of SK2, the lower thoracic of SK4, and the mid thoracic to first sacral of SK5. These lesions are common in most skeletal populations and indicate physical stress affecting the back.

SK2 had slight anterior epiphyseal dysplasia on the superior edge of the 11th thoracic vertebra. This is an avascular necrosis of the bone, probably caused by a lack of blood supply to the affected area. It is likely to be related to physical stress on the spine.

SK1 showed numerous lesions which were probably associated with habitual movements, and therefore perhaps occupational in origin. A shallow pit $(c 7 \mathrm{~mm}$ diameter) had formed at the centre of the right humerus head, corresponding with a slightly raised area in the centre of the scapula glenoid, probably the beginnings of an osteochondritic lesion. There were two vertical, parallel exostoses $c 20 \mathrm{~mm}$ long on the distal posterior surface of the right femur at the insertion for the medial head of the gastrocnemius muscle. A similar exostosis, $c 16 \mathrm{~mm}$ long, had formed on the medial supra-condylar line of the left femur, to which the adductor magnus is attached. Smaller, more rounded exostoses had formed on the medial side of the proximal tibia at the attachment for the semimembranosus. The principal actions of these muscles are to flex the knee and ankle and to rotate the leg slightly. A small oval exostosis, $6 \mathrm{~mm}$ by $3 \mathrm{~mm}$, had also formed at the proximal end of the left femur linea aspera just below the third trochanter. Pitting and slight new bone growth was observed at the proximal ends of both ulnae at the insertion of the triceps.

Several small exostoses at the inion suggested tearing of the muscle attachments between the neck and the back of the skull of SK5. A torn muscle may also have caused the slight pitting, suggestive

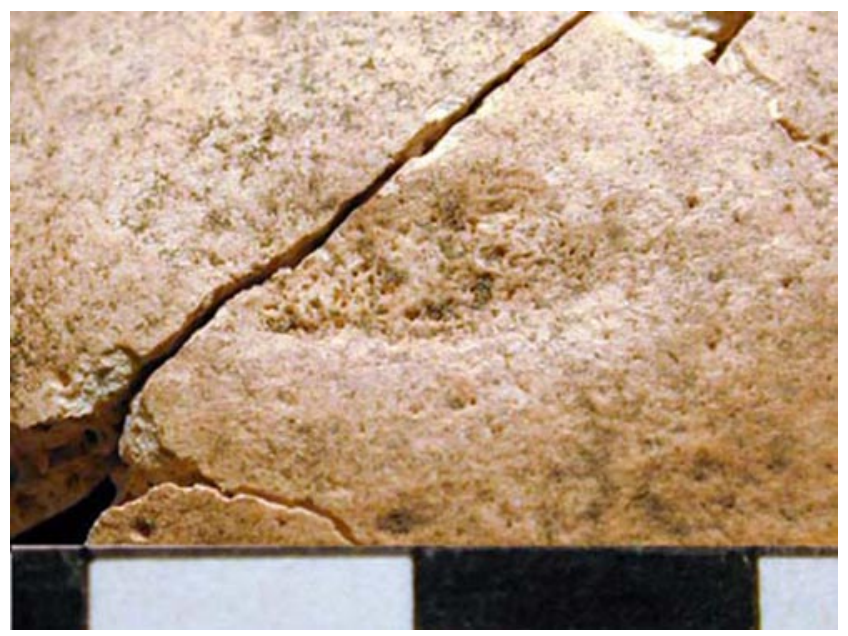

Illus 12 Depressed fracture on the right side of the frontal bone of SK5

of an inflammatory response, at the right radial tuberosity.

SK5 also showed evidence of several injuries which may have been the result of direct violence. There were well-healed and remodelled fractures of at least three right ribs, two in two places (illus 11). The fractures occurred at the back, side and front of the torso. A well-healed fracture of the second metatarsal midshaft was also substantially remodelled and showed only slight evidence of inflammatory response in the form of pitting. On the right side of the frontal bone there was a small oval lesion, $13 \mathrm{~mm}$ by $5 \mathrm{~mm}$ and shallow with a pitted floor, which was probably a depressed fracture (illus 12 ).

\subsubsection{Infectious disease}

Sinusitis was present in all three maxillary sinuses, generally consisting of porosity and slight thickening on the floor of the sinus. New bone growth was 
present in the left maxillary sinus of SK5, and this individual was also affected in the frontal sinuses.

SK1 had a slight periosteal new bone deposit on the midshaft of the left fibula with pitting and slight thickening close to the broken end, and there was also slight graining and rounded new bone growth with enlargement of the bone at the anterior distal third of the left tibia. The right tibia was also affected with graining, enlargement and pitting midshaft on the anterior medial surfaces.

Fragments of SK5's right tibia show graining and thickening medially and similar new bone growth was present on the posterior surface of the right fibula shaft. The left tibia shaft was enlarged with thick new bone, generally smooth with slight pitting at the proximal end, graining at the soleal line and to the posterior of the medial side. There was rough disorganised new bone growth just medial and inferior to the anterior tubercle and at the proximal end of the interosseous line. Deep venous impressions were present on the lateral surface. The left fibula was also affected, with deep graining and new bone growth, particularly on the interosseous surface but also some laterally midshaft. No venous bridging or lytic lesions which might suggest syphilis were present, and there were no cloacae to suggest osteomyelitis, so these lesions can only be classified as non-specific periostitis.

\subsubsection{Miscellaneous}

Both coronoid fossae of the humeri of SK1 had circular holes which revealed the trabecular bone beneath (right $8 \mathrm{~mm}$ diameter, left $7 \mathrm{~mm}$ diameter). These could be incomplete septal apertures, or possibly developmental defects due to occupational use. A thick area of new bone, a kind of torus, had formed above the left. A similar thick torus of new bone had formed above the right coronoid fossa of SK4.

\subsection{Summary and discussion}

At least six individuals were identified in this assemblage. All were probably male, and only one was younger than 18 years of age. Two individuals were probably below 30 , and two were identified as middle-aged or old, perhaps in the range 40-60 years.

In terms of physical appearance, the group was too small to make any useful generalisations, although it is noticeable that all four individuals for whom stature could be estimated had above-average heights when compared with other contemporary groups. Non-metric traits and congenital anomalies were noted, but there was no evidence for any familial relationships between these individuals.

One individual in this group had been particularly badly affected by dental caries, and this had resulted in abscess formation and subsequent tooth loss. The abscesses which formed in the jaw of a second individual were not periapical and were more likely to have been related to gingivitis and poor dental hygeine. A high degree of dental disease is normal for early post-medieval groups, but susceptibility also increases with age, and both individuals affected in this group were probably over 40 .

For such a small group, there was a relatively high degree of bone disease. The usual degenerative changes were observed in the spines and some other joints of the middle-aged and older individuals. Four of the five skulls in the assemblage showed evidence for either deficiency disease or a scalp infection. Stress lesions were common, particularly in the spine, and may have been occupationally induced in at least one individual. One of the older men showed evidence for at least one violent incident which had left him with several broken bones and a mild cranial lesion. All three individuals for whom the maxillary sinuses were present had been affected by sinusitis, and this may be connected with living or working in a smoky atmosphere. Two individuals had periostitis of the shin bones, one of them chronic, but this is a relatively common pathology in most groups. Whilst it can be related to specific infections such as syphilis, leprosy and osteomyelitis, there was no evidence for the cause in these examples. It can also be related to varicose vein formation, or even to infections in the soft tissue in other areas of the body.

Radiocarbon dating has shown these individuals to be of early post-medieval date, with stratigraphic evidence suggesting that they belonged to the 16th or early 17 th centuries. Dental analysis has provided corroboration, as two of the four main inhumations showed signs of clay pipe attrition on the anterior teeth. This would indicate a date later than the mid 16 th century. Other skeletal remains have been found in the area on the opposite side of Constitution Street, in the vicinity of Wellington Street and on Leith Links, and these have been attributed to the plague in 1645 (Russell 1922). This post-dates the construction of Balmerino House, so it seems unlikely that these individuals were buried here as a result of that incident. The Siege of Leith in 1560 also resulted in a large number of deaths. However, the presence of disarticulated bone within the fill of two of the graves would appear to indicate further burials, and therefore a long-term cemetery rather than a temporary solution to a crisis.

The approximate north-south alignment of the graves is unusual in Christian churchyards generally, and could perhaps indicate a burial place for executed criminals. At Oxford Castle the bodies of executed criminals of the 16th-18th centuries were discovered buried with little care, some face down and many aligned north to south (Poore 2004). The churchyard of St Margaret in Combusto, Norwich, was the burial place of locally hanged felons, and several burials excavated here were orientated north-south or south-north (Stirland 2009). 
It is thought that the intention was to deny these criminals a proper Christian burial. Whilst none of the Leith men showed any evidence of hanging, it is very unusual for such evidence to survive in skeletal material. Fracture of the hyoid bone, once thought to be a good indicator of hanging as cause of death, is actually found to occur only rarely (Naik $\&$ Patil 2005). The Leith Tolbooth, not far from here in Tolbooth Wynd, was built in 1564 and if this area was open land at the time it is possible that this was the closest ground available for the purposes of burial of executed prisoners.

However, the burials may originally have lain within the boundary of a much larger parish churchyard than now exists, and possible reasons for their burial on this site are discussed further below. 


\subsection{Pottery, by Derek Hall and George Haggarty}

This excavation produced 243 pieces of pottery, ranging in date from the 12 th to the 18 th centuries. Each sherd has been identified by eye and where possible assigned a recognised fabric name and provenance.

\subsubsection{Medieval wares}

198 of the sherds are in variations of Scottish White Gritty Ware (SWGW), assumed to be a local product, which began production in the 12th century (Jones et al 2003). The largest group, from the fill of a Phase 3 pit (338), is very abraded, indicating that this material has been moved around quite a bit. Sherds from Phase 1 (from the fill of the well and the gully) and Phase 4, associated with SK5, are very thick and would seem to belong to the later end of this industry, dating to the 15 th century. There are good parallels for this material from previous excavations in Leith at both Burgess Street and Ronaldson's Wharf (Lawson forthcoming a \& b).

Vessels in the distinctively glazed fabrics of Yorkshire-type Ware were the most common imports in the east coast burghs in the 13th and 14th centuries (McCarthy \& Brooks 1988, 227-52). There were two sherds from the large Phase 3 pit (338) and the Phase 1 well (262), which are both from glazed jugs.

\subsubsection{Late and post-medieval wares}

Scottish Post-Medieval Oxidised Ware (SPMOW) was first identified in excavations at Stirling Castle in the late 1970s (Haggarty 1980). It represents a late-medieval transition from the Scottish Redware fabrics produced from the 13th century and dates from the mid 15th to mid 18th centuries. There are 31 sherds in this assemblage and the most common vessel type is the green-glazed jug.

Phase 2 (midden 226) produced one tiger-glazed grey Frechen/Cologne stoneware body sherd dated to $c$ 1600-1650 and one basal angle sherd from a slightly under-fired white stoneware jug covered with a light-brown exterior glaze, which has a double cordon above the expanded and rounded foot. Vessels of this type are rare in this fabric and are generally thought to be Cologne products, but this example has evidence of the diagnostic concentric arcs of Frechen on its base.

Phase 3 produced one body sherd from what may be a Martincamp flask; the exterior is a reduced orange-brown colour and the interior buff.
Phase 4 (Context 212) produced one late Saintonge buff-coloured body sherd from the shoulder of a vessel which has a single spot of glaze on its exterior and groove at what is probably the junction of neck and shoulder. Also from this context is an unglazed, abraded and heavily rilled body sherd in pale pink fabric, which has abundant tiny mica inclusions. It is probably French, but not Saintonge, and from a small jug or similar vessel.

Associated with SK5 is one body sherd from the shoulder of a Siegburg vessel, probably a jug, which is covered on its exterior with an orange-brown ash glaze. There are two shallow grooves at the junction of the neck and shoulder. It probably dates to $\mathrm{AD}$ $1450-1550$.

Phase 4 (sand layer 212 sealing the skeletons) produced one small body sherd from a large Redware crock with reduced core. Phase 5 (Context 208) produced a small, unglazed strap handle fragment in a sandy fabric with a reduced core, pinkish surfaces and sooting. This may be an early example of Scottish post-medieval Redware affected by secondary firing (16th century?).

The Phase 5 dump of clay smoking pipes (214) produced one rim fragment from a Hurst-type C.VIII Saintonge chafing dish which has an applied green-glazed arcaded knop, the beginning of another and interior sooting (illus 13, no. 13). John Hurst published, in considerable detail, a catalogue of the then known chafing dish variants (Hurst 1974, 233-47) of which only a few of the more uncommon types are known from Scotland. The only other recorded Scottish example of a Hurst-type C.VIII chafing dish comes from Ayr (Franklin \& Hall forthcoming) and these can be paralleled by two examples from Plymouth (Clark 1979, 30) and an almost complete example from Grimsby Lane, Hull (Watkins 1993, 106, fig. 74, no. 261), dated $c 1550$.

There was one unstratified sherd of fine orangered sandy Merida-type ware, covered with a lead glaze on its interior surface and a green glaze on the majority of its exterior but which stops with a definite line about $20 \mathrm{~mm}$ from the bottom. The sherd also thickens markedly towards the bottom, suggesting that it may be near the base and that it might be from a bowl. The sherd possibly dates from c 1575 to $c 1625$.

One small rim sherd from a Low Countries Redware pipkin was recovered as an unstratified find. A very small sherd of thinly potted Tin Glazed Earthenware in an off-white fabric was also an unstratified find; this open vessel has traces of cobalt-blue decoration on its exterior and dates to the late 17 th or 18 th century. 

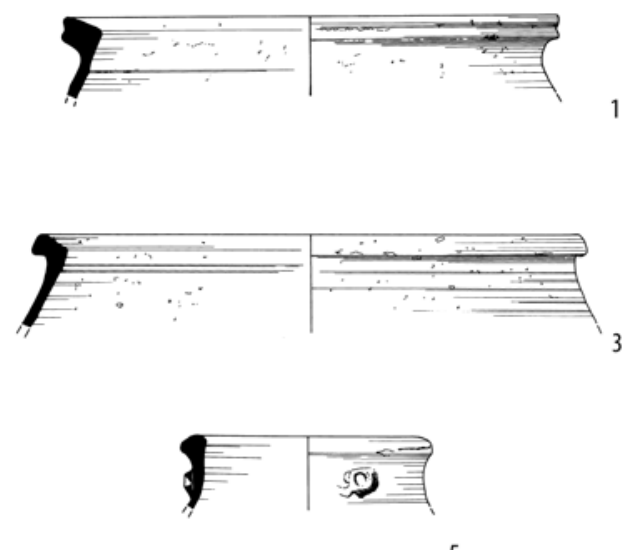

5

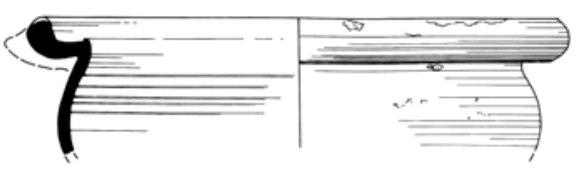

9

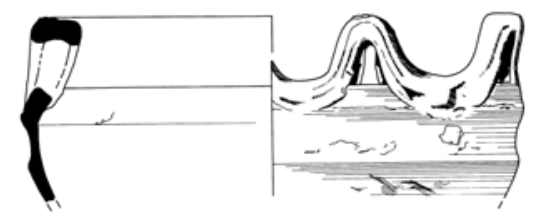

11
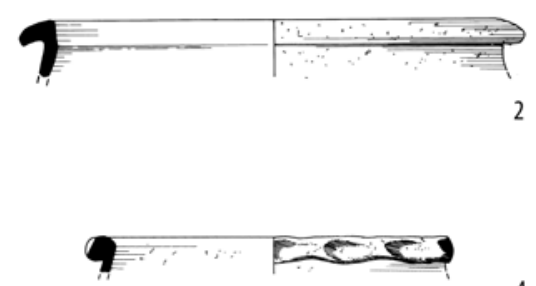

4
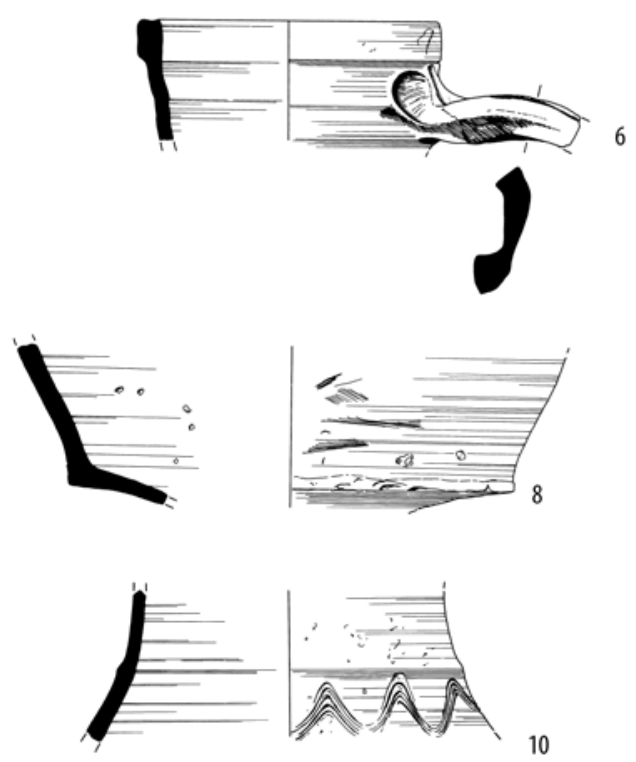

10

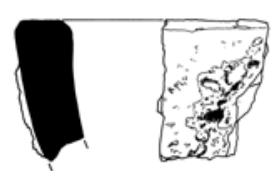

12

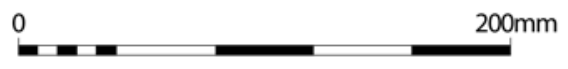

Illus 13 Pottery

\subsubsection{Unidentified}

A Phase 5 levelling deposit produced one rimsherd from a small, thin, all over lead-glazed vessel. This is of uncertain origin and date as it does not appear to be Scottish Post-Medieval Oxidised Ware and may be 18th-century.

\subsubsection{Discussion and conclusions}

This assemblage is very mixed, containing several late-medieval continental imports, but it seems unlikely that any of them were found in situ. This is also reflected in the medieval assemblage, where many of the sherds of Scottish White Gritty Ware are very abraded and have clearly been moved around.
The discovery of a rimsherd from a Hurst-type C.VIII chafing dish serves to confirm that excavations in Leith are always very likely to discover late-medieval imported wares that are not well represented in other parts of Scotland.

\subsubsection{Illustrated pottery (illus 13)}

1. SWGW abraded rimsherd from unglazed jar. Step foundation 206, Phase 5.

2. SWGW rimsherd from unglazed jar. Gravel layer 235, Phase 3.

3. SWGW rimsherd from unglazed jar. Gravel layer 235, Phase 3.

4. SWGW frilled rimsherd from unglazed jar. Pit fill 337, Phase 3. 
5. SWGW rimsherd from jug with traces of green glaze and applied red clay 'eye'. Sump lining 239 , Phase 5.

6. SWGW rim and handle junction from greenglazed jug. Midden layer 226, Phase 2.

7. SWGW narrow-ribbed rod handle from jug with traces of green glaze. Deposit 212, end of Phase 4.

8. SWGW basal angle from unglazed vessel. Well fill 264, Phase 1.

9. SPMOW rimsherd from vessel internally glazed green with traces of external smoke blackening. Drain fill 243, Phase 5.

10. SPMOW bodysherd from jug glazed green-brown with incised wavy decoration. Gravel layer 235, Phase 3.

11. A rimsherd from a Saintonge Ware Hurst-type C.VIII chafing dish with green-glazed applied arcaded knob. Deposit 212, end of Phase 4.

\subsection{Clay pipes, by Dennis Gallagher}

A total of 117 clay pipe fragments comprising 14 bowls, 12 mouthpieces and 91 stems were examined from eight different contexts, the majority being from one context in Phase 5 (sump fill 214). None of the context groups were large but Context 214 with 89 fragments including 11 bowls, is of particular interest as it consists of apparent wasters. A full catalogue can be found in the site archive.

All the pipes appear to be local products, having a small bulbous bowl with a heel. The form is one common to many production centres in the early 17th century, before regional characteristics were fully developed. The largest group consisted of a deposit of wasters, unused bowls and other fragments, from Context 214. These are generally similar to the pre-1637 sealed group from the Tron Kirk (Gallagher 1987, 270). Stylistically most of the bowls from Context 214 can be dated to $c$ 1630-40. The exception is one bowl which is slightly later, $c$ 1650. This is a long-necked, forward-leaning bowl marked with a $\mathrm{W}$ on one side of the base, the other side being illegible. This mark may be identified as a product of William Banks. Banks held a monopoly of Scottish pipemaking in the early 17 th century and, while this did not go unchallenged, the ubiquity of his products in excavated groups of the mid 17th century would suggest that he held most of the market. It is probable that the other pipes from Context 214 are his products. Although initially based in the Canongate, by 1635 he was resident in Leith. It is not known from the documentary evidence if he manufactured pipes in Leith, but the existence of the present waster material would suggest that this was the case. Recent excavations, including the present one, have uncovered more marked pipes from this period but more work is required on development of the early forms to refine dating.

The pipes are in a variety of fabrics, including red and grey clay as well as the more normal white.
One bowl and a number of stem fragments show signs of over-firing, resulting in a grey fabric with a gritty surface. All the bowls are from low-quality products, with their rims bottered (smoothed) but not milled. Several of the heels are trimmed at an angle. Only one of the bowls has a maker's mark: a basal stamp that has a very crude rendering of the castle motif that became almost ubiquitous on later Edinburgh products. Only two fragments, both stems, are burnished. Certain of the stems are defective, having holes in their length caused by extremely off-centre bores. A few stems are bent at a sharp angle. Others have a gritty, or partially gritty, grey fabric, some with splashes of dark glaze. Some of the glaze splashes cover the breaks. As glaze was not used on pipes of this period, it would suggest that they shared a kiln with a potter's products. Few fragments joined, but from stem thickness and taper it is estimated that the average stem length was approximately $200 \mathrm{~mm}$.

Two stems had decoration consisting of multiple lines of milling applied with a roller stamp. Whilst uncommon on Edinburgh products, it has been noted on a pipe of mid 17th-century date recovered from recent excavations at Tower Street, Leith (Franklin forthcoming).

Mouthpieces rarely survive intact in assemblages of Edinburgh pipes, as they were the narrowest part of the stem and thus very fragile. The relatively large number of mouthpieces from Context 214 suggests that they were dumped very quickly after manufacture. All were of a simple rounded form formed in the mould, the usual form found on 17th-century Edinburgh products.

\subsection{Ceramic building material and fired clay, by Sue Anderson}

\subsubsection{Kiln furniture}

Fragments of heavily vitrified fired-clay kiln lining and pieces of kiln furniture were recovered from Phase 4 and 5 contexts, a total of 34 fragments $(11,555 \mathrm{~g})$. Some fragments were recovered from the Phase 4 midden layer 212. In Phase 5, the majority were associated with clay pipes in dump 214, but small pieces were also found in nearby features: drain 207, sump fills 231 (sump 240) and 237 (sump 230). Terminology in the following descriptions follows Peacey (1996).

Most of the pieces were heavily vitrified kiln lining and were $60+\mathrm{mm}$ thick. The vitrified surface was generally dark brown with deep cracks and the clay itself was white-firing and appeared to be tempered with ferrous or grog inclusions. One exception was a red brick (65mm thick) tempered with calcareous material, which was covered in thick slag-like vitrified material. In one case the vitrified surface was convex, perhaps suggesting that it covered an internal buttress.

Pieces of probable kiln structure were also present. 
A short 'column' consisting of four U-shaped tiles in white firing clay, welded together by vitrification, measured $130 \mathrm{~mm}$ in height, $90 \mathrm{~mm}$ wide and $92 \mathrm{~mm}$ deep; the surfaces were vitrified and deeply cracked. Another piece appeared to consist of fragments of two similar tiles stuck together.

Fragments of six possible 'bats' were identified. These were roughly formed in white-firing clays, some containing grog and others ferrous material, and with smoothed surfaces and rounded edges. They varied in width from $64 \mathrm{~mm}$ to $91 \mathrm{~mm}$. Thicknesses varied from $22 \mathrm{~mm}$ to $40 \mathrm{~mm}$, although most were under $30 \mathrm{~mm}$ thick. There was also a possible saggar or dish (illus 13, item 12) which appeared to be bowl-shaped in form, $c 300 \mathrm{~mm}$ in diameter, and had two ?rectangular cut-outs $c 37 \mathrm{~mm}$ below the rim and $30 \mathrm{~mm}$ apart. None of the examples provided by Peacey have cut-outs, however.

Six pieces of 'furniture supplements' were found. These consisted of four fragments of two thin, flat sheets or straps (4mm thick), a Type 4 'bun' with a roughly curving edge $(9 \mathrm{~mm}$ thick, $c 320 \mathrm{~mm}$ in diameter) and a heavily vitrified fragment which may have had a rolled edge.

The only evidence that the pieces represented pipe-kiln waste comes from their association with clay pipe wasters dated $c$ 1630-40 (see Gallagher at 6.2 above). Whilst some of these pieces show similarities to 19th-century pipe-kiln waste, particularly the flat straps or sheets, none of the fragments had impressions of pipe stems or bowls on their surfaces, and there were no waste fragments of slag-like material containing clay pipe stems. However, there is at present very little evidence for early pipe kilns and it may be that the types of kiln furniture in use in this early period were slightly different from those of the 19th century. If these fragments were from a pipe kiln, they are clearly of great importance in the early history of clay pipe manufacture in Scotland.

\subsubsection{Illustrated sherd (illus 13)}

12. Fragment from white-firing clay saggar. Drain 207, Phase 5.

\subsubsection{Brick and tile}

Two fragments $(785 \mathrm{~g}$ ) of ceramic building material were collected. There was a small piece of floor tile with honey-coloured glaze, $32 \mathrm{~mm}$ thick, from fill 271 of the Phase 1 curving wall foundation cut. A handmade brick in a red, medium sandy grogtempered fabric was found in Phase 3 pit 338 (fill 335 ); it measured $110 \mathrm{~mm}$ wide and $45 \mathrm{~mm}$ thick, a size compatible with a date in the 16th century.

\subsubsection{Terracotta, by Adam Jackson}

A terracotta trefoil (unstratified) has been broken at its stem and probably once formed the decorative end of a ridge tile from a roofed structure or coping from a wall. It would originally have been formed by pressing clay into a mould and then being fired in a brick kiln. Such building components were, in the 19th century, mass-produced by numerous companies across the UK, and would have appeared in sales catalogues that were widely available. In the absence of a maker's stamp it is impossible to identify the origin of this object. The trefoil or shamrock is a common decorative motif, particularly in church architecture, as it symbolises both perpetuity and the Holy Trinity.

\subsection{Stone, by Adam Jackson}

A fragment of sandstone carved in a scroll form, and with feather or leaf detailing, was an unstratified find. The latter had breaks at both ends and probably formed part of the decoration on the top of a tombstone or some other funerary or commemorative monument. Scrollwork is commonplace on funerary and commemorative monuments, particularly from the 18th century to the present day. It is probable, however, that the object is broadly, but not definitely, of 19th-century date.

\subsection{Glass, by Sue Anderson}

Seven fragments of glass were collected, two unstratified, three from deposits, one from a drain fill and one from a pit fill. They included shards of window, bottle and vessel glass.
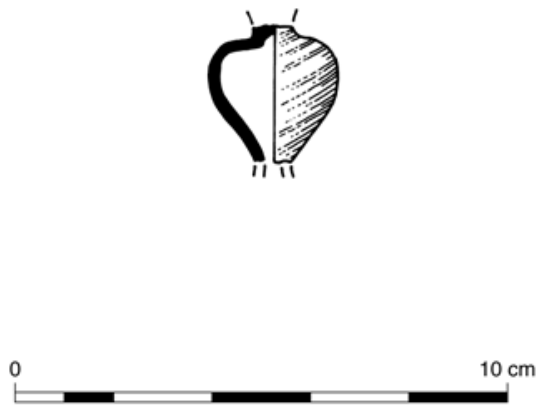

Illus 14 Glass stem

The earliest find in this small assemblage was a wine-glass fragment from Phase 5, the fill of sump 230 (illus 14). It is a hollow-blown inverted baluster-shaped knop in slightly opaque, very pale green ?soda glass, and was part of the stem of a late 17th-century wine glass. It is likely to have been imported, possibly either Venetian or Dutch, and would not have been out of place on the tables of Balmerino House. A fragment of unstratified 17thcentury window glass with a muff edge shows signs of burning, perhaps evidence of a house fire if it was 


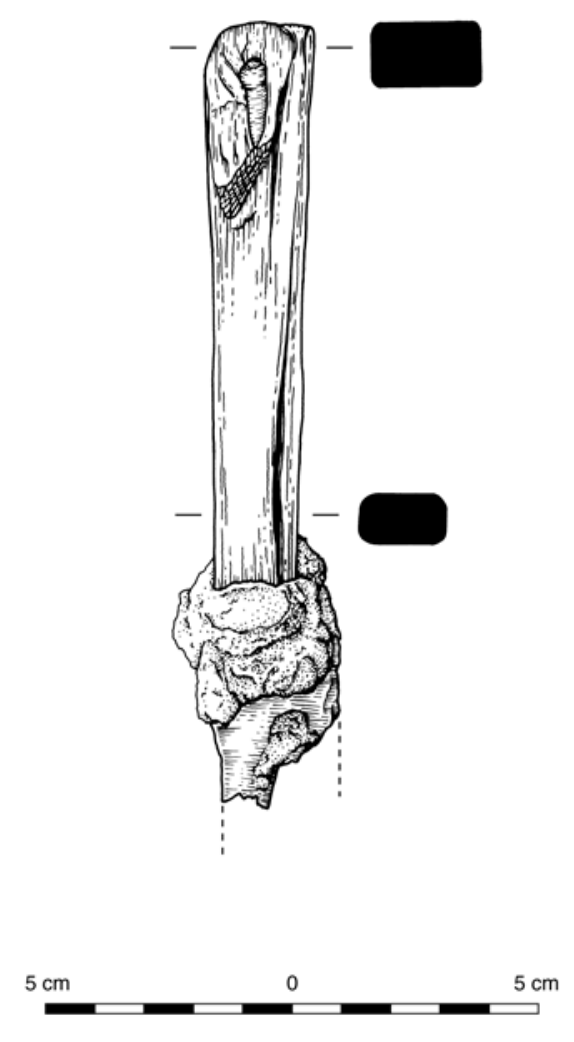

Illus 15 Knife

in situ at the time. Nothing else in this group is of particular note, consisting of post-medieval green beer/wine bottles which occur commonly on sites of 17 th- to early 20 th-century date, a very fragmentary window quarry of uncertain date, and a fragment of modern uncoloured window glass. A full catalogue can be found in the site archive.

\subsection{Metalwork, by Sue Anderson}

\subsubsection{Textile-working objects}

A copper alloy machine-made thimble was found in Phase 5 (foundation-levelling Context 225). It had flaring sides, a domed end and concentric rings of dots at the top, and was slightly squashed. The height was $24 \mathrm{~mm}$ and the diameter was $c 20 \mathrm{~mm}$ at the open end. Machine-made thimbles were first produced in the Netherlands in the 17th century (Margeson 1993, 187), so it is possible that this object could be contemporary with its context.

\subsubsection{Tools}

An iron blade-tool (illus 15), probably a large knife, with a plain, rectangular-section, tapering handle of ivory, was found in Phase 4 (Context 212). The handle was $c 120 \mathrm{~mm}$ long, $22 \mathrm{~mm}$ wide and $13 \mathrm{~mm}$ thick. The blade, which was heavily corroded and incomplete, had a long tang (67mm long). A further length $(37 \mathrm{~mm})$ of a more radio-dense metal circular- section rod was present at the opposite end of the handle, the end of which can be seen at a break in the ivory. This may indicate that the current blade was a replacement. A similar handle, used for a mirror, was found at South Berwick, New England, at a site which is closely datable to the third quarter of the 17th century (Baker n.d.).

\subsubsection{Nails and miscellaneous fittings}

The majority of ironwork collected from this site consisted of nails, a total of 32 objects. All except one were handmade, with square- or rectangularsection shafts, and where heads were present these were flat, sub-square sheet types. The exception was an unstratified fragment that was either a machinemade nail or a fragment of straight wire. Complete nails varied in length from $37 \mathrm{~mm}$ to $71 \mathrm{~mm}$, although one incomplete example was over $84 \mathrm{~mm}$ long.

Six nails were collected from contexts associated with skeletons SK4 and SK5 and could be coffin nails, although they may simply have been redeposited in the grave fills as there were so few. Two of these nails had very large square heads and could be classified as studs.

Mineral-preserved wood was present on eight nails from the fill of Phase 5 drain 207 (pine) and unphased wall foundation fill 271 (oak) (species identifications by M Cressey).

A fragment of rectangular plate or strap $(22+\mathrm{mm}$ long, $16 \mathrm{~mm}$ wide, $2 \mathrm{~mm}$ thick), with a dome-headed rivet ( $7 \mathrm{~mm}$ diameter) in situ and a hole for another at the broken end, was an unstratified find. The degree of preservation suggested it was probably modern.

A curving strap fragment $(127+\mathrm{mm}$ long, $18 \mathrm{~mm}$ wide, $8 \mathrm{~mm}$ thick) with a rectangular section came from Phase 2, midden 226. It may be part of a drop handle of the type used on chests, coffins or drawers. A square rivet hole was present at one end.

\subsubsection{Unidentified}

Two concreted lumps of iron in very poor condition were found with SK2. One of these had mineralpreserved wood within the corrosion products, but it was unidentifiable (M Cressey pers comm). Radiographs suggest that at least one of the fragments may be ferrous slag.

A fragment of an object with a rectangular section (49+mm long, $12 \mathrm{~mm}$ wide, $8 \mathrm{~mm}$ deep) was found in Phase 2, midden 226.

\subsection{Vitrified material, by Dawn McLaren and Andrew Heald}

Eight samples of vitrified material or slag were recovered during the excavations. Visual examination allows the material to be broadly classified 
using standard terminology (eg McDonnell 1994; Spearman 1997; Starley 2000). Slags can be produced during a range of pyrotechnic processes and are not necessarily indicative of ironworking. A range of slag morphologies are produced during iron production and generally fall into two types: macro-slags and micro-slags. Only a few, for example tapped slag and hammerscale, are truly diagnostic (of smelting and smithing respectively). In many slag assemblages there is a significant amount of material which is unclassifiable, making the allocation of individual pieces - particularly small samples - to specific types and processes difficult (Crew \& Rehren 2002, 84). Further scientific analyses would be necessary to classify the material more conclusively. Only macroslags were recovered from the excavations. None of the micro-slags that may suggest in situ ironworking (eg hammerscale) were recovered. Further, only a few of the pieces could be confidently assigned to iron-working, possibly smithing.

One piece (892g) from the fill of Phase 3 pit 282, appears to be an amalgam of at least two slag pieces. One lump appears to be superimposed on a compact, dense slag retaining the sub-rectangular form of the hearth/furnace structure. Vitrified slag adheres to the upper surface and one side. The small dimensions and lack of substantial charcoal inclusions may suggest that this is likely to be the result of iron smithing rather than smelting activities where hearth bottoms appear to be larger and heavier, with large inclusions of charcoal or organic material.

The remaining seven slags do not have any diagnostic features which allow them to be classified to specific types; the pieces are, therefore, best described as unclassified slags. Such slags are a common component within a slag assemblage and, as noted, can be produced during a range of pyrotechnic processes and not just ironworking. They often form the bulk of an assemblage and can be present in a wide variety of sizes and a range of colour and density. Recognising class by visual examination alone is difficult and for this reason such slags are often referred to as undiagnostic slags (US). This assemblage is dominated by such material, with $576 \mathrm{~g}$ coming from five contexts. Possible inclusions of coal and lime within the vitrified matrix suggest a medieval or post-medieval date. The majority of the slag (354g) was unstratified and tells us little about on-site activities.

\subsubsection{Discussion}

This small assemblage was derived from secondary or residual contexts and is consequently limited in the information that it can provide about on-site activities. The vitrified material is dominated by unclassified slags, the majority from unstratified contexts, which are neither diagnostic of a specific ironworking process nor chronologically distinctive. Only one fragment, the slag amalgam encompassing a plano-convex hearth bottom, is diagnostic of smithing activities. The absence of micro-slags, such as hammerscale or slag spheres, and associated structural elements (eg hearth or furnace lining) does not indicate in situ metalworking. The stratified material was mainly recovered from medieval or post-medieval deposits (Phase 3 (282) and Phase 4 (212)) that predate the foundation walls of Balmerino House. The use of coal and possibly lime detected within the vitrified material is consistent with a medieval or post-medieval date.

\subsection{Worked bone, by Catherine Smith}

A broken cattle first phalange from Phase 4 shows some modification of the proximal articular surface: a small, smooth-edged, circular hole was bored into the proximal surface, placed centrally in the natural groove between the peripheral and abaxial halves of the bone. The hole penetrates into the internal cavity of the bone. It is probable that the intention was to produce an artefact of some sort, since trying to extract marrow from the bone by this means would have resulted in a larger, rougher hole. In any case, very little marrow would have been produced for the effort expended.

Perforated cattle phalanges interpreted as toys or gaming pieces are known from sites dating from the late Neolithic and the Iron Age in the Northern Isles (Sharples 1984, 105-6) as well as from urban medieval sites in mainland Scotland and the Netherlands. Phalanges from medieval Dunfermline (Cox 1996, 99, cat. no. 121) and 16th-century Dokkum (van Gelder-Otway 1979, fig. 2,115), with more than one piercing, are probably intended as miniature skittles. The holes were possibly used to introduce lead into the interior of the bone, in order to weigh the pieces down. The phalange from Leith may be an example of this type of artefact, although given its incompleteness, it is not possible to state this with certainty.

\subsection{Animal bone, by Catherine Smith}

\subsubsection{Species present}

Table 3 shows the species present by phase. Species which were present in all phases were cattle and sheep/goat, both being equally frequent (168 fragments each). Pig bones were present in Phases 2, 4 and 5 and were far less frequent than either cattle or sheep/goats, totalling only 15 bones. Horse bones were present in Phases 1, 2 and 4 (ten bones) and were also recovered from unstratified contexts. Other domesticated animals present were cat (eight bones from Phases 2, 4 and 5) and dog, represented by seven bones in Phase 2 and an unstratified skeleton, SK3. Wild mammals were represented by a single bone of ?fox (Vulpes vulpes) in Phase 4, one bone of hare (Lepus capensis) in Phase 3 and three of rabbit (Oryctolagus cuniculus) in Phases 2 and 5. 
Table 3 Animal and bird bone species quantification by phase

\begin{tabular}{|c|c|c|c|c|c|c|}
\hline \multirow[b]{2}{*}{ Species } & \multicolumn{5}{|c|}{ No. of bones } & \multirow[b]{2}{*}{ Total } \\
\hline & Phase 1 & Phase 2 & Phase 3 & Phase 4 & Phase 5 & \\
\hline Cattle & 23 & 54 & 17 & 35 & 39 & 168 \\
\hline Sheep/goat & 22 & 56 & 10 & 43 & 37 & 168 \\
\hline Pig & & 11 & & 3 & 1 & 15 \\
\hline Horse & 1 & 4 & & 5 & & 10 \\
\hline Roe deer & 1 & & & & 1 & 2 \\
\hline Dog & & 7 & & & & 7 \\
\hline Dog/Fox & & & & 1 & & 1 \\
\hline Cat & & 5 & & 2 & 1 & 8 \\
\hline Hare & & & 1 & & & 1 \\
\hline Rabbit & & 1 & & & 2 & 3 \\
\hline Large ungulate & 9 & 37 & 10 & 13 & 28 & 97 \\
\hline Small ungulate & 3 & 17 & 3 & 10 & 29 & 62 \\
\hline Indeterminate mammal & 34 & 93 & 26 & 81 & 38 & 272 \\
\hline Domestic fowl & 7 & & & 2 & 15 & 24 \\
\hline Grey partridge & 1 & & & & & 1 \\
\hline Domestic/Greylag goose & 2 & & & 1 & 3 & 6 \\
\hline Duck cf Mallard & & & 1 & & & 1 \\
\hline Gannet & & 1 & & & & 1 \\
\hline Gull species & & & & & 1 & 1 \\
\hline Indeterminate bird & 1 & 4 & 2 & & 5 & 12 \\
\hline Fish & + & & & + & & + \\
\hline Total & 104 & 290 & 70 & 196 & 200 & 860 \\
\hline
\end{tabular}

Roe deer (Capreolus capreolus) bones were present in Phases 1 and 5.

Bird species found at the site were domestic fowl (Gallus gallus), grey partridge (Perdix perdix), domestic/greylag goose (Anser anser), duck cf mallard (Anas platyrhynchos), gannet (Sula bassana) and gull species (Laridae). An unphased context (271) contained the skeleton of a domestic fowl.

\subsubsection{Ages of animals at death}

Epiphyseal fusion state was examined to provide evidence of the ages at which animals were killed or died. Long bones with surviving articular ends were scrutinised to determine whether fusion of the epiphyseal plates had taken place. Bones were then categorised as belonging to one of the following age categories: juvenile; juvenile or immature; immature; immature or adult; and adult. There was thus a certain amount of overlap between the age categories, due to the degree of variation in timing of epiphyseal closure between individuals. This method of estimating age at death is generally agreed to be more imprecise than that derived using dental criteria. However, sheep/goats were the only species for which there was dental evidence of age at death at the site and thus it was the only method available for cattle.

In the case of cattle, no bones of very young animals were recovered. A small percentage of bones, 9.3\%, did however fall into the juvenile or immature category, and represent calves. The remainder of the bones came from animals which were immature or adult at death. Cattle which were definitely adult accounted for 50\% of the sample. These figures, however, represent a fairly small sample and should therefore be treated cautiously. Preservation factors should be taken into account, bearing in mind that bones of younger animals are less highly mineralised than those of adults and thus under adverse burial conditions survive less well. The distribution pattern is therefore likely to be skewed towards older individuals. The presence of adult individuals indicates that animal husbandry was of a sufficiently high standard to allow the survival of many animals over several winters before culling. These animals may represent the breeding stock.

By contrast, there is evidence that more sheep were killed at a young age, borne out by both the mandibular and long bone evidence. The cull 
pattern showed no marked dissimilarities between the earlier phases (1-4) and later Phase 5.

\subsubsection{Individual animal burials}

Two more or less complete animal skeletons were recovered from the site. One, SK3, was a male dog, buried in front of Balmerino House and thought to be a pet animal. On the basis of tooth wear and overall dental health, this dog was probably an older adult. In the left mandible, the canine, first and second premolars were all missing. Since there was a degree of resorption of the jaw bone it was evident that the teeth had been lost during life (ante mortem). The dog was otherwise healthy, at least in regard to the evidence of the skeleton. In appearance, it would have been of the 'plain dog' type, the skull having a fairly wide zygomatic arch, a muzzle neither unduly long nor short and a well-developed sagittal crest. Its estimated height (after Harcourt 1974) was approximately $49 \mathrm{~cm}$, or about the size of a modern Border collie.

The second skeleton was that of a domestic fowl (Context 271). Although the head and beak were missing, most of the post-cranial skeleton was present. There was evidence of some pathology in the pelvis: the synsacrum was deformed, with a severely twisted vertebral column, skewed to the right side. The lumbo-sacral vertebrae were also markedly skewed. The long bones of the legs were normal in appearance, despite presumably having been forced to compensate for the deformities in the pelvis. There was little further evidence of pathology apart from expansion of two rib facets. The bird may have died naturally, or was perhaps in too poor a condition before death to have been considered fit for human consumption.

\subsubsection{Butchery}

There was plentiful evidence of butchery style and the types of implements used. In all phases there was little evidence that saws had been used. Instead, the main implements used to disjoint and divide carcasses of cattle, sheep/goats and pigs appear to have been axes or cleavers. This was apparently the norm throughout Scotland in the medieval and post-medieval periods.

Most of the butchery marks appear to have been made by individuals with a modicum of skill, requiring only one or two cuts to sever a bone or joint. However, one bone in Phase 5, a cattle scapula, has been subjected to a barrage of blows, resulting in a series of about 16 hacking cuts on the ventral surface. The positions of the hacks near to the neck indicate that the intention must have been to sever the joint between the scapula and the humerus, although this appears to have proved a difficult task for the butcher. By contrast, in one context in Phase 2, the flesher seems to have disjointed articulating bones using only a knife: deep cuts are apparent around the tubercles of a proximal cattle tibia at the knee joint, and a cattle calcaneum (tarsal) shows knife cuts on the shaft and the proximal end, characteristic of boning out by a skilled operator.

There were also two examples of horse butchery. A horse radius from Phase 2 , although entire, had been hacked at least eight times along the medial and proximal part of the shaft, in a medio-lateral direction. If the intention was to sever the lower part of the leg, the job was unfinished. In the same context, a left metatarsal, possibly from the same horse, showed evidence of parallel knife cuts on both the anterior and posterior aspects of the shaft. The marks on the metatarsal possibly relate to skinning, although those on the radius hint at removal of the meat rather than the hide.

A horse radius/ulna associated with dog skeleton SK3 was sawn across the shaft near to the olecranon process. In addition, knife cuts and cleaver hacks were present on the medial aspect of the radius shaft. This appears similar to the way in which cattle radii are butchered, and also indicates meat production. Horses have been butchered and their meat eaten by humans, or prepared as dog food, throughout Scotland from the Iron Age to the early modern period (Smith 1998), and to find evidence of this practice in Leith in both medieval and postmedieval contexts is not surprising.

\subsubsection{Size of the animals}

Several intact long bones of sheep survived, allowing an estimation of live withers height (or height at the shoulder) to be made. In the case of sheep, two radii in Phases 1-4 were estimated to come from animals of $57.3 \mathrm{~cm}$ and $60.7 \mathrm{~cm}$, while a metacarpal and metatarsal from Phase 5 were from sheep of about $53.8 \mathrm{~cm}$ and $58 \mathrm{~cm}$ respectively. These animals fall within the range of 46.7-65.8cm recorded on the large medieval assemblage from the Marks and Spencer site, High Street, Perth (Hodgson et al forthcoming).

Two complete horse radii were recovered, from which withers heights were estimated. One bone from Phase 2 was from an animal standing approximately $140 \mathrm{~cm}$, or about $13: 3$ hands' height at the shoulders, and another from Phase 4 was from an animal of about $126 \mathrm{~cm}$, or 12:1 hands. Both of these animals are smaller than 14:2 hands, the defining upper height limit for ponies, and thus can be considered as such.

In general, most of the bones from Phases 1 to 4 at the site fell within the size ranges of those from the substantial medieval assemblage recovered from the Marks and Spencer site, High Street, Perth and other medieval assemblages from Scotland. One bone, a cattle calcaneum from Phase 1, appeared substantially larger than the medieval norm, perhaps indicative of disturbance or re-deposition from elsewhere. 


\subsubsection{Discussion}

The range and frequency of occurrence of the domestic and wild mammal and bird species recovered from the site is typical of a Scottish medieval urban assemblage. Cattle and sheep/ goats were the mainstay of the domestic economy and were the most frequently occurring species at this site, as they are at many other sites on the east coast of Scotland (Hodgson 1983). Pigs were much less frequent than either cattle or sheep/goats, as is the case at other medieval Scottish sites. The diet of the inhabitants of the site may also have included horse flesh, although it is possible that the butchered horse bones were the remains of meat prepared as food for dogs.

Wild mammals, such as hare and roe deer, were also utilised, but their bones were nowhere near as plentiful as those of the domesticates. It is not possible to state whether the rabbit bone in Phase 2 was from an animal which was eaten, since it was unbutchered. If medieval, it is an early example of a species whose introduction from continental Europe was only established with some difficulty by monastic communities. However, since the rabbit is well-known for its burrowing habits, it is fairly likely that the bone is intrusive.

Both domestic and wild birds were also eaten. The former included domestic fowl, goose and possibly duck, although the last could as easily have been a wild mallard as a domestic bird. Wild species were the grey partridge, a well-known game bird up to the present day, and the gannet, a species which is not so widely used as in the past. Gannet bones have been recovered from sites of medieval date both around and on the islands of the Firth of Forth, for example North Berwick, Dunbar and the Isle of May (Smith 2008 and forthcoming) and are evidence of seasonal exploitation of marine resources.

\subsection{Overview of the finds and dating evidence, by Sue Anderson}

Finds from Phase 1 consisted largely of pottery and animal bone. One small fragment of a late-medieval floor tile was also found. Most of the pottery came from the well feature 262 and ditch 274 , and suggests that the former was probably of 13th/14th-century date, and that both had been infilled in the 15th century. Recut pit 276/280 produced two sherds of post-medieval oxidised ware, suggesting a date no earlier than the 15th century.

Overlying the Phase 1 features, a thick layer of midden soil or abandonment horizon contained large quantities of animal bone, a small group of medieval and post-medieval pottery, an iron ?handle and a piece of slag. The mixed nature of the deposit suggests that it may have been reworked as a garden or cultivation soil. This may explain the presence of apparently intrusive material such as the Frechen stoneware sherd of 16th/17th-century date. It is likely that this deposit was originally laid down in the 15 th century.

The earlier of the two Phase 3 pits (338) produced 77 sherds of medieval pottery, including some Scarborough Ware, much of which was abraded. The large pit (282), which cut 338, produced only one sherd of post-medieval oxidised ware, but also contained a half-brick of probable 16th-century date. A small quantity of animal bone and two pieces of slag were also recovered from these features, but it seems likely that many of the finds, from pit 338 at least, were redeposited from earlier layers.

Phase 4 included the remains of six human skeletons, the bones of which produced radiocarbon dates spanning the mid 15 th to mid 17 th centuries. The presence of clay pipe wear on the teeth of two individuals suggests a date towards the end of this range. As clay pipes were not widely available until the 1590s in England (and were not made in Scotland until the 1620s), a date in the later 16th or early 17th century would seem most likely for the burials. Residual pottery of medieval and mid 15thto mid 16th-century date was recovered from soil surrounding two of the burials.

The majority of artefacts from Phase 4 came from the layer sealing the burials. Again there was a high proportion of residual material in this layer (212), including medieval pottery and probably animal bone. The latest pottery consisted of late Saintonge Ware and post-medieval oxidised wares. A clay pipe of $c$ 1640-60 was recovered, as well as a shard of window glass, and a few pieces of kiln waste also came from this layer. The iron blade tool with the ivory handle, potentially also of 17 th-century date, came from this layer. It seems likely that, like the Phase 2 midden layer, this layer represents reworked garden soil.

Finds from Phase 5 were collected from the make-up layers below the step foundation, the foundation itself, and the fills of pits, sumps and drains. Seventeen sherds of medieval and fifteen of post-medieval pottery were recovered, including the possible Merida Ware vessel and the Saintonge chafing dish rim. Other finds included animal bones, a 17th-century or later thimble and a fragment of late 17th-century wine glass. The largest group of finds from this phase consisted of the kiln waste and clay pipe fragments from dump layer 214. Given the presence of some of this material in the Phase 4 layer overlying the skeletons, it is possible that the material was redeposited following the excavation and creation of sump 240 and used to backfill the earlier, defunct sump 230. If so, it must be presumed that the waste was dumped on the site whilst it was still waste ground, prior to the construction of Balmerino House in 1631. It seems unlikely that it would be dumped in the grounds after the house had been built.

Material from the 20th-century Phase 6 demolition of the house was all of modern date and, with the 
exception of a piece of slag, no finds were recovered from contexts of this phase.

Unphased material included the decorative terracotta and stone fragments which could have been related to St Mary's itself, several shards of glass bottles, a dog burial, some iron slag and pottery collected from test pit contexts. 


\section{$7 \quad$ SITE NARRATIVE}

\subsection{3th-to 15th-century occupation}

The earliest phase of site use appears to be as a yard area and probably dates from the 13th century. The earliest pottery found on the site was recovered from the backfill of the well (262) and is dated to the 13 th or 14 th centuries AD, suggesting that the well was in use in the high medieval period. The large pit (285) in the south of the site shows that sandquarrying was taking place, presumably to extract building materials for the expanding town.

\subsection{5th/16th-century abandonment or cultivation?}

The site-wide Phase 2 layer (226) and the lack of any evidence for a property division suggests that the area formed a single unit in the 15th-16th centuries. The land in this phase contained midden material, including butchered animal bones. Some evidence of skilled butchery of a range of animals possibly indicates that a trade butcher worked nearby, or perhaps owned and used the land. However, it seems most likely that during this period the land was used simply for cultivation, or even stood empty for a time.

\subsection{6th-century sand quarrying}

The two large pits (282) and (338) probably represent sand-quarrying for use in building materials for the ever-expanding town. This practice was confined to the south of the site, as the north of the site was relatively undisturbed in this phase. They were adjacent to Phase 1 pit 285 . Presumably the earlier pit was uncovered and found to contain unsuitable sand, and therefore the new quarries were moved slightly further east to get the desired material. The material used for backfilling of these pits contained concentrations of abraded pottery, indicating their deliberate in-fill with residual material which may be derived from earlier middening. The brick from the latest fill suggests a final infilling in the 16th century. The presence of these quarries is further evidence for the apparent abandonment of the site in the previous phase.

\subsection{Late 16th-/early 17th-century burial ground}

The ground was used for human burial at some point between the mid to late 16th century and up to 1631 . The radiocarbon date range puts the skeletons between 1440 and 1650; this date range is reduced when finds dated to the 16 th century which were recovered from the deposits that the graves were cut through, are considered. The presence of dental attrition attributed to the smoking of clay pipes would suggest that the skeletons were buried after the introduction of tobacco pipes to Britain in the late 16th century. Balmerino House was built in 1631 , and it is unlikely that bodies would have been buried outside the front door of the house. Thus, a date of approximately 1590 to 1631 could be inferred from the evidence presented above.

There are at least two explanations for the presence of these burials within the grounds of Balmerino House. One possibility is that the burials were of soldiers killed in the Siege of Leith in 1560. The stature of the skeletons (above average height at that time), and the site's proximity to the eastern defensive wall of the French-built town fortifications, lends some weight to this interpretation. However, this is credible only if the wear seen on the teeth of two of the two skeletons was caused by something other than clay pipe use, and this is doubtful.

The favoured explanation is that the burials were originally part of a formal cemetery, based on the following evidence. South Leith parish church, originally a chapel dedicated to St Mary and attached to the collegiate church of Restalrig, is situated on Constitution Street, some $120 \mathrm{~m}$ to the south of these burials. The church was used as a parish church from the 1560s following the demolition of Restalrig Church, although this status was not formally confirmed until 1609 . The church occupies a roughly central position within the present graveyard. If these burials were originally part of it, then the graveyard must have been truncated by the expansion of Leith Town in the 17th century. The presence of disarticulated remains of at least two further individuals suggests that a dedicated, long-term graveyard was located here, rather than a short-term burial ground. The approximate northsouth alignment of these burials remains an enigma, especially given the apparent conformity of the rows of graves within the current churchyard, but it is at present unknown how common this practice might have been in post-medieval Scottish churchyards.

\subsection{7th-century manor house and gardens}

Balmerino House was built by John Stewart, Earl of Carrick in 1631 and sold to Lord Balmerino in 1643. Major development and landscaping of the site took place with its construction. The ground was landscaped and raised to create ornamental gardens. 
The excavation revealed the position of the entrance stairway and the garden retaining wall in front of the house. The foundations bear little resemblance to the shape of the splayed staircase shown on the illustration published by Grant (1882), although presumably the easternmost line of the footings represents the position of the bottom step, with the other walls supporting the sweep up to the front door.

To each side of the stairway, elements of the repair of domestic drainage for the house were revealed, in the form of Phase 5 sump tanks (230 and 240). After sump 230 filled up and became unusable, the second sump (240) was dug and a new drainage culvert (210) constructed. The old sump was latterly backfilled with a dump of malformed clay smoking pipes, most of which date from 1630-40, with one exception that dates from 1650 . Therefore a date after 1650 can be assigned to the abandonment and realignment of the sumps, and presumably either the construction or extension of the staircase.

The building and land were sold to the church in 1848. St Mary's Star of the Sea Roman Catholic Church was built on part of the garden in 1853, and Balmerino House was finally demolished in the 1970s. 


\section{CONCLUSIONS, with Sue Anderson}

The excavation at St Mary's Star of the Sea has revealed evidence of late- to post-medieval activity in South Leith. The site changed from backyards, to a quarry, to a graveyard and then to a manor house and gardens, probably within a timescale of approximately 200 years, with two apparent periods of disuse in between. The excavation has provided new information about the late- to post-medieval development and land use in this part of Leith, and provided some insight into the construction techniques for a large house of the early 17 th century and its services.

The radiocarbon dates, along with the finds, confirmed that the skeletons were probably buried in the 16th or early 17 th century. This paper considered two explanations for the presence of these burials. The first is that they were originally interred in the graveyard of South Leith parish church situated in close proximity on Constituition Street, and that the graveyard was truncated during the expansion of Leith Town in the 17th century. The second is that they were the remains of soldiers who died and were buried during the Siege of Leith, particularly in view of the fact that the men were above average height for the time and therefore likely to have been well-nourished. There was no evidence in their bones for any kind of trauma which might have been responsible for their death, but this does not preclude violence or hanging. Whichever explanation is accepted, there is no doubt that they were buried apparently without record and were soon forgotten. Their place of rest was soon to be developed into formal gardens and they lay undisturbed outside the steps of Lord Balmerino's grand mansion until long after its own demise. 


\section{ACKNOWLEDGEMENTS}

The authors would like to thank Paul Gowdy of Gregor Properties, John Lawson (the City of Edinburgh Council Archaeologist), and Eddie and Graham Grant from Expert Excavations. Dating samples were identified by SueAnderson and assayed at SUERC Radiocarbon Laboratory, Scotland. Illustrations were produced by Karen Clarke and Alan Braby. Earlier drafts of this report were commented upon by Melanie Johnson and Tim Neighbour.
While thanks are due to the above, responsibility for the final form and content lies with CFA Archaeology Ltd and the authors.

The site archive has been deposited with the National Monuments Record of Scotland and finds will be allocated through Treasure Trove procedures. 


\section{REFERENCES}

Anderson, S 1998 'Pathology of some 17th-century prisoners from Norwich Gaol', in SAnderson (ed), Current and Recent Research in Osteoarchaeology. Oxford (=Procs 3rd Meeting Osteoarchaeol Res Group).

Anderson, $\mathrm{S}$ forthcoming 'The human bone', in $\mathrm{R} J$ Cramp, 'Report on the excavations at The Hirsel, Coldstream', for Historic Scotland.

Baker, E n.d. 'The Humphrey \& Lucy Chadbourne Archaeology Site', [http://www.salemstate.edu/ ebaker/chadbourne.html]

Clark, A 1979 'French Wares' in C Gaskell Brown, Plymouth Excavations: Castle Street, The Pottery. Plymouth (=Plymouth Museum Archaeol Ser, No. 1).

Cox, A 1996 'Bone and antler objects', in R Coleman, 'Excavations at the Abbot's House, Maygate, Dunfermline', Tayside Fife Archaeol J, 3, 99-100.

Crew, P \& Rehren, T 2002 'High temperature workshop residues from Tara: iron, bronze and glass', in H Roche (ed), Excavations at Ráith na Rig, Tara, Co. Meath, 1997. Dublin (=Royal Irish Academy Discovery Programme Reports, 6).

Franklin, J forthcoming 'Clay Pipes' in report on excavations at Tower Street, Leith.

Franklin, J and Hall, D W forthcoming 'The pottery' in D Perry, 'Excavations in the medieval burgh of Ayr'.

Gallagher, D B 1987 'Edinburgh, Tron Kirk' in P Davey (ed) The Archaeology of the Clay Tobacco Pipe.X.Scotland,269-71. Oxford (=BritArchaeol Rep, Brit Ser, 178).

van Gelder-Otway, S 1979 'Faunal remains from Dokkum', Palaeohistoria, XXI, 110-26.

Grant, J 1882 Old and New Edinburgh. Cassell, London [http://www.oldandnewedinburgh. co.uk/].

Haggarty, G 1980 'The pottery', in G Ewart, 'Excavations at Stirling Castle', Post-Medieval Archaeology, 14, 23-51.

Harcourt, R A 1974 'The dog in Prehistoric and early historic Britain', Journal of Archaeological Science, 1, 151-75.

Harris, S 1991 'The fortifications and siege of Leith: a further study of the map of the siege in 1560', Proc Soc Antiq Scot, 121, 359-68.

Hodgson, G W I 1983 'The animal remains from medieval sites within three burghs on the eastern Scottish seaboard', in B Proudfoot (ed), Site, Environment and Economy, 3-32. London (=Brit Archaeol Rep, International Series, 173).

Hodgson G W I; Smith, C and Jones, A forthcoming 'The mammal bone' in N Q Bogdan; G W I Hodgson; C Smith; A Jones; M Fraser; D Heppel;
A S Clarke; A K G Jones; I H M Smart; R B Longmore; R Cerón-Carrasco \& D McKay, The Perth High Street Excavation. Fascicule IX. The environmental evidence. Historic Scotland.

Hurst, J G 1974 'Sixteenth- and seventeenthcentury imported pottery from the Saintonge', in I Evison; H Hodges \& J G Hurst (eds), Medieval Pottery from Excavations: Studies Presented to Gerald Clough Dunning, 221-55. J. Baker, London.

Jones, R; Haggarty, G; Hall, D W \& Will, R 2003 'Sourcing Scottish White Gritty Ware', Medieval Ceramics, 26-27 (2002-03), 45-84.

Lawson, J forthcoming a 'Excavations at Burgess Street, Leith'.

Lawson, J forthcoming $\mathrm{b}$ 'Excavations at Ronaldson's Wharf, Leith'.

Margeson, S 1993 Norwich Households. Medieval and Post-Medieval Finds from Norwich Survey Excavations 1971-78. Norwich (=E Anglian Archaeol Rep, 58).

Mays, S 1990 Twelve 18th-century Skeletons from Launceston Castle, Cornwall. Ancient Monuments Lab. Rep. 77/90. Unpublished.

McCarthy, M \& Brooks, C M 1988 Medieval Pottery in Britain $A D$ 900-1600. Leicester University Press, Leicester.

McDonnell, G 1994 'Slag report', in B Ballin Smith (ed), Howe: Four Millennia of Orkney Prehistory. Excavations 1978-82, 228-34. Edinburgh (=Soc Antiq Scot Monogr Ser, 9).

Mowat, S 1994 The Port of Leith. Forth Ports in association with J. Donald Publishers, Edinburgh.

Naik, S K \& Patil, D Y 2005 'Fracture of hyoid bone in cases of asphyxial deaths resulting from constricting force round the neck', $J$ Indian Acad Forensic Med, 27 (2005), 149-53.

Peacey, A 1996 'The development of the tobacco pipe kiln in the British Isles', Internet Archaeol 1 [http://intarch.ac.uk/journal/issue1/peacey_ index.html].

Poore, D 2004 'Latest images from Oxford Castle', Oxford Archaeology [http://www.oau-oxford. $\mathrm{com} / \mathrm{html}$ pages/oxfordcastle_march04.htm, accessed 21/2/2006].

Russell, J 1922 The Story of Leith. Thomas Nelson \& Sons Ltd, Edinburgh [http://www.electricscotland.com/history/leith/].

Sharples, N M 1984 'Excavations at Pierowall Quarry, Westray, Orkney', Proc Soc Antiq Scot, 114 (1984), 75-125.

Smith, C 1998 'Dogs, cats and horses in the Scottish medieval town', Proc Soc Antiq Scot, 128 (1998), 859-85.

Smith, C 2008 'The animal bone', in S Mitchell, 
'Medieval North Berwick revealed: excavations in Forth Street', Trans E Lothian Antiq \& Field Naturalists Soc 27, 49-71.

Smith, C forthcoming "The bird bones from the Isle of May'. Historic Scotland/ GUARD/ SUAT archive report.

Spearman, R M 1997 'The smithy and metalworking debris from Mills Mount', in S T Driscoll \& P A Yeoman (eds) Excavations within Edinburgh Castle in 1988-91, 164-8. Edinburgh (=Soc Antiq Scot Monogr Ser, 12).

Starley, D 2000 'Metalworking debris', in K Buxton \& C Howard-Davis (eds), Bremetenacum: Excavations at Roman Ribchester 1980, 1989-1990, 337-47. Lancaster (=Lancaster Imprints Ser, 9).
Stirland, A 2009 Criminals and Paupers: the Graveyard of St Margaret Fyebriggate in Combusto, Norwich, E. Anglian Archaeol. 129.

Stronach, S 2002 'The medieval development of South Leith and the creation of Rotten Row', Proc Soc Antiq Scot, 132, 383.

Watkins, G 1993 'The pottery', in D Evans (ed), Excavations in Hull 1975-76, 75-145. Hull (=East Riding Archaeologist, vol 4, Hull Old Town Rep Ser No 2).

White, R 2004 St Mary's Star of the Sea, Leith (Area A). Archaeological Evaluation and Excavation. CFA Report No. 931. Unpublished archive report. 